\title{
Inhibition of Calcium Oxalate Formation and Antioxidant Activity of Carboxymethylated Poria cocos Polysaccharides
}

\author{
Chuang-Ye Li, ${ }^{1}$ Li Liu, ${ }^{1}$ Yao-Wang Zhao ${ }^{1},{ }^{1}$ Jia-Yun Chen, ${ }^{2}$ Xin-Yuan Sun, ${ }^{2}$ \\ and Jian-Ming Ouyang $\mathbb{B D}^{2}$ \\ ${ }^{1}$ Department of Urology, Hunan Children's Hospital, Changsha 410007, China \\ ${ }^{2}$ Institute of Biomineralization and Lithiasis Research, Jinan University, Guangzhou 510632, China \\ Correspondence should be addressed to Yao-Wang Zhao; yw508@sina.com and Jian-Ming Ouyang; toyjm@jnu.edu.cn
}

Received 23 November 2020; Revised 30 January 2021; Accepted 16 February 2021; Published 2 March 2021

Academic Editor: Mansur A. Sandhu

Copyright (C) 2021 Chuang-Ye Li et al. This is an open access article distributed under the Creative Commons Attribution License, which permits unrestricted use, distribution, and reproduction in any medium, provided the original work is properly cited.

\begin{abstract}
Three carboxymethylated Poria cocos polysaccharides (PCP-C1, PCP-C2, and PCP-C3) with -COOH contents of $6.13 \%, 10.24 \%$, and $16.22 \%$, respectively, were obtained by carboxymethylation of the original polysaccharide (PCP-C0), which has a molecular weight of $4 \mathrm{kDa}$ and a carboxyl $(-\mathrm{COOH})$ content of $2.54 \%$. The structure of the PCP-Cs was characterized by FT-IR, ${ }^{1} \mathrm{H}$ NMR, and ${ }^{13} \mathrm{C}$ NMR spectra. The four PCP-Cs exhibited antioxidant activity, and their ability to scavenge radicals (hydroxyl and $\mathrm{DPPH}$ ) and chelate ferrous ions was positively correlated with the degree of carboxymethylation. As the content of - $\mathrm{COOH}$ groups in the PCP-Cs increases, their ability to regulate the growth of calcium oxalate (CaOx) crystals was enhanced, thus inhibiting the growth of calcium oxalate monohydrate (COM) crystals and inducing the formation of more calcium oxalate dihydrate (COD) crystals. The formed $\mathrm{CaOx}$ crystal was more round and blunt, the absolute value of the Zeta potential on the crystal surface increased, and the aggregation between crystals was inhibited. Thermogravimetric analysis curves showed that the proportions of PCP-C0, PCP-C1, PCP-C2, and PCP-C3 incorporated into the crystal were 20.52\%, 15.60\%, 10.65\%, and $9.78 \%$, respectively, in the presence of $0.4 \mathrm{~g} / \mathrm{L}$ PCP-Cs. PCP-C protection resisted oxidative damages of human kidney proximal tubular epithelial cells (HK-2) caused by oxalate, resulting in increased cell viability and superoxide dismutase activity and decreased reactive oxygen species levels, malondialdehyde content, and 8-hydroxy-deoxyguanosine expression. Hence, PCP-Cs, especially $\mathrm{PCP}-\mathrm{C} 3$, can inhibit the formation of $\mathrm{CaOx}$ crystals and may have the potential to be an alternative antistone drug.
\end{abstract}

\section{Introduction}

Kidney stones are a very common disease and are believed to be the result of the interaction between the genetic and environmental factors. About $80 \%$ of kidney stones are calcium oxalate $(\mathrm{CaOx})$ stones, and the two main forms are calcium oxalate monohydrate $(\mathrm{COM})$ and calcium oxalate dihydrate (COD) [1]. COM is more likely to damage renal epithelial cells [2]; the cell damage will promote the nucleation, growth, aggregation, and adhesion of crystals on its surface [3], thereby increasing the formation risk of kidney stones.

Polysaccharides are widely found in plants, animals, and microorganisms. Natural polysaccharides possess antioxidant, antidiabetic, antitumor, and other biological activities. The biological activity of polysaccharides is usually related to their molecular weight and chain structure, especially the number of active groups $[4,5]$.

Biomacromolecules (such as polysaccharides) rich in acidic polyanionic groups can be used as effective inhibitors of $\mathrm{CaOx}$ calculus formation. Zhang et al. [6] found that $0.5 \mathrm{~g} / \mathrm{L}$ Sargassum polysaccharide can inhibit the growth and aggregation of COM crystals and induce the formation of spherical COD crystals; the inhibition rates of crystal nucleation and aggregation are $69.2 \%$ and $76.8 \%$, respectively.

The biological activity of polysaccharides is closely related to the content of acidic groups [7-10]. Xu et al. [9] extracted two polysaccharides from E. acuminatum; the neutral polysaccharide EAP- $1 \mathrm{~N}$ has a uronic acid content of $0.32 \%$, and the acid polysaccharide EAP-2A has a uronic acid content of $9.46 \%$. EAP-2A has a stronger ability to scavenge 
free radicals, enhance the activity of antioxidant enzymes (including superoxide dismutase (SOD), catalase (CAT), and glutathione peroxidase (GSH-Px)), and inhibit lipid peroxidation. Huang et al. [10] compared the effects of five plant polysaccharides (PPSs) with -COOH contents of $6.3 \%, 8.9 \%$, $9.1 \%, 13.6 \%$, and $16.1 \%$, respectively, on the growth of $\mathrm{CaOx}$ crystals; the ability of PPSs to inhibit $\mathrm{CaOx}$ growth and aggregation and induce COD formation was positively correlated with the percentage of $-\mathrm{COOH}$ groups in the polysaccharide.

Chemically modified polysaccharides show stronger biological activity than natural polysaccharides [11-15]. Wang et al. [11] modified Poria cocos polysaccharide by carboxymethylation and reported that the polysaccharide with the highest carboxymethylation degree had the highest chelating ability to ferrous ions and the highest scavenging ability to hydroxyl radicals. Wang et al. [13] prepared carboxymethylated polysaccharide (CATP) from Tremella polysaccharide (ATP) and found that CATP had significantly higher antioxidant activity and improved water solubility than ATP. Li et al. [15] treated hypercholesterolemic rats with a high dose of Morchella angusticeps Peck polysaccharide (PMEP) and its carboxymethylated polysaccharide (CPMEP) and reported that the serum total cholesterol levels of rats were 1.54 and $1.29 \mathrm{mmol} / \mathrm{L}$, respectively; hence, CPMEP has stronger cholesterol-lowering activity and can upregulate the protein expression of CYP7A1 and LDL-R in rat livers, downregulate the expression of HMG-CoA, and improve its cholesterollowering ability.

$P$. cocos polysaccharide (PCP) is one of the main components of $P$. cocos [16] and can be used to treat chronic gastritis, nephropathy, dizziness, and vomiting [17]. PCP is mainly composed of four monosaccharides, namely, Dglucose, D-mannose, D-fucose, and D-xylose [18, 19]. Wang et al. [20] found that PCP extracted by an ultrasonic wave has the ability to reduce power and scavenge hydroxyl and DPPH radicals. Wu et al. [21] showed that PCP can inhibit acetaminophen-induced liver injury in mice and reduce the levels of the serological liver enzyme (ALT), lactate dehydrogenase (LD), and inflammatory cytokines (TNF- $\alpha$, IL-6).

In this study, three carboxymethylated polysaccharides (PCP-C1, PCP-C2, and PCP-C3) with - $\mathrm{COOH}$ contents of $6.13 \%, 10.24 \%$, and $16.22 \%$, respectively, were obtained by carboxymethylation of Poria polysaccharide (PCP-C0) with initial $-\mathrm{COOH}$ content of $2.54 \%$. Inhibitory effects on the formation of calcium oxalate crystals were studied in vitro to obtain potential anticalculus polysaccharide drugs.

\section{Experimental Methods}

\subsection{Materials and Apparatus}

2.1.1. Materials. Poria cocos polysaccharide (PCP-C0) was produced by Shaanxi Ciyuan Biological Company, with polysaccharide content $\geq 95 \%$; the protein present in polysaccharide was removed by the Sevag method; after treating the polysaccharide with the chloroform-n-butanol mixed solution, the free protein is denatured into insoluble substances and the purpose of separation is achieved [22]. Phosphate-buffered solution (PBS), phenazine, 1,1-diphenyl-2-picrylhydrazyl (DPPH), phenanthroline, and other conventional reagents were of analytical grade and were purchased from Guangzhou Chemical Reagent Company (Guangzhou, China). The Cell Counting Kit-8 (CCK-8) was purchased from Dojindo Laboratory (Kumamoto, Japan). $\quad 2^{\prime}, 7^{\prime}$-Dichlorodihydrofluorescein diacetate (DCFH-DA) was purchased from Shanghai Beyotime Bio-Tech Co., Ltd. (Shanghai, China). The malonaldehyde (MDA) kit and superoxide dismutase (SOD) kit were purchased from Jiancheng Institute of Biotechnology (Nanjing, China). The Human 8-hydroxy-deoxyguanosine (8OHdG) ELISA Kit was purchased by Boshen Biotechnology (Nanjing, China). The experimental water is doubledistilled water.

2.1.2. Apparatus. The apparatus used in the study included the following: Fourier transform infrared spectrometer (FTIR, Nicolet, USA); nuclear magnetic resonance (Varian Bruker-500 MHz, Bruker, Germany); ultrasonic apparatus (aligned with JP-100S); Ubbelohde capillary viscometer (0.4-0.5, Qihang Glass Instrument Factory, Shanghai, China); thermogravimetric analyzer (TGA/DSC 3+, Mettler Toledo, USA); D/max 2400-X-ray powder diffractometer (Rigaku, Japan); field emission scanning electron microscope (ULTRA55, Zeiss, Germany); OPTIMA-2000DV inductively coupled plasma (ICP) (ICP-AES, Optima 2000DV, PerkinElmer, CT, USA); Zetasizer 300HS nanoparticle size-Zeta potential analyzer (Malvern, UK); and Enzyme Mark Instrument (Safire ${ }^{2}$, Tecan, Switzerland).

\subsection{Carboxymethylation and Characterization of Poria cocos Polysaccharides (PCP-CO)}

2.2.1. Carboxymethylation of PCP-CO [23-25]. $300 \mathrm{mg}$ PCP$\mathrm{C} 0$ was suspended in $15 \mathrm{~mL}$ of isopropanol, stirred at room temperature for $15 \mathrm{~min}$, slowly added $10 \mathrm{~mL}$ of $30 \% \mathrm{NaOH}$ solution, stirred at $50^{\circ} \mathrm{C}$ water bath for $1 \mathrm{~h}$, then added $2.63 \mathrm{~g}$ of monochloroacetic acid, and then heated at $60^{\circ} \mathrm{C}$ for $2 \mathrm{~h}$. After cooling to room temperature, adjust to neutrality with $0.5 \mathrm{~mol} / \mathrm{L} \mathrm{HCl}$, dialyze with distilled water $(\mathrm{Mw}$ retention $3000 \mathrm{Da}$ ) for 3 days, and concentrate and freezedry to obtain carboxymethylated polysaccharides (PCP-Cs) with different degrees of substitution.

2.2.2. Determination of -COOH Content in PCP-Cs [26]. - $\mathrm{COOH}$ content of PCP-Cs was determined by the method of conductometric titration. The conductivity titration curve was plotted using the conductivity value as the $Y$-axis and the used $\mathrm{NaOH}$ volume as the $X$-axis. From the conductivity titration curve, the volume of $\mathrm{NaOH}$ consumed by polysaccharide- $\mathrm{COOH}$ is obtained, and the percentage of $-\mathrm{COOH}$ is calculated. Each experiment was repeated three times.

2.2.3. FT-IR Characterization of PCP-Cs. FT-IR spectra of polysaccharides were determined using films prepared by 
$2.0 \mathrm{mg}$ of the dry PCP-C sample and $200 \mathrm{mg} \mathrm{KBr}$ in the wavenumber range of $4000-400 \mathrm{~cm}^{-1}$.

2.2.4. ${ }^{1} \mathrm{H}$ and ${ }^{13} \mathrm{C} N M R$ Characterization of PCP-Cs. Approximately $20 \mathrm{mg}$ of the dry PCP-C sample was dissolved in $0.5 \mathrm{~mL}$ of deuterated water $\left(\mathrm{D}_{2} \mathrm{O}\right)$ in an NMR tube. After being completely dissolved, the polysaccharide sample is put into a magnetic field of a nuclear magnetic resonance spectrometer for detection.

\subsection{Antioxidant Activity Detection of PCP-Cs}

2.3.1. Hydroxyl Radical ( $\mathrm{OH}$ ) Scavenging Capacity. The $\mathrm{OH}$ scavenging ability of polysaccharides in vitro was detected by the $\mathrm{H}_{2} \mathrm{O}_{2} / \mathrm{Fe}$ system method [27]. Add $1 \mathrm{~mL} 2.5 \mathrm{mmol} / \mathrm{L}$ $\mathrm{FeSO}_{4}$ solution and $1 \mathrm{~mL} 2.5 \mathrm{mmol} / \mathrm{L}$ phenanthroline solution to the test tube, then add PBS $(20 \mathrm{mmol} / \mathrm{L}, 1 \mathrm{~mL}, \mathrm{pH}=$ 7.4) and $1 \mathrm{~mL} 20 \mathrm{mmol} / \mathrm{L} \mathrm{H}_{2} \mathrm{O}_{2}$ in sequence, and finally take $1 \mathrm{~mL}$ of different concentrations of polysaccharide samples $(0.15,0.5,0.8,1.0,2.0$, and $3.0 \mathrm{~g} / \mathrm{L})$ into test tubes. After mixing well, incubate at $37^{\circ} \mathrm{C}$ for $90 \mathrm{~min}$ and use a UV spectrophotometer to measure the absorbance at $536 \mathrm{~nm}$; the average absorbance is $A_{3}$. Each experiment was repeated three times. The absorbance when hydrogen peroxide $\left(\mathrm{H}_{2} \mathrm{O}_{2}\right)$ and polysaccharide solution were replaced with distilled water was $A_{2}$. The absorbance when polysaccharide solution was replaced with distilled water was $A_{1}$. The ascorbic acid (VC) was used as the positive control group. The ability to scavenge hydroxyl radicals was calculated using the following equation:

$$
\text { Scavenging effect }(\%)=\frac{\left(A_{3}-A_{1}\right)}{\left(A_{2}-A_{1}\right)} \times 100 \% \text {.. }
$$

2.3.2. DPPH Radical Scavenging Capacity [28, 29]. $0.4 \mathrm{mmol} / \mathrm{L} \mathrm{DPPH}$ was prepared by anhydrous ethanol, and $3 \mathrm{~mL}$ PCP-C $(0.15-3 \mathrm{~g} / \mathrm{L})$ polysaccharide was mixed with DPPH $(0.4 \mathrm{mmol} / \mathrm{L}, 1 \mathrm{~mL})$. The mixture was incubated in the dark at $25^{\circ} \mathrm{C}$ for $30 \mathrm{~min}$. The absorbance is detected at $517 \mathrm{~nm}$ to reflect the DPPH radical scavenging ability of polysaccharides. Each experiment was repeated three times.

$$
\text { Scavenging effect }(\%)=\left[1-\frac{\left(A_{2}-A_{1}\right)}{A_{0}}\right] \times 100 \% \text {. }
$$

where $A_{2}$ was the absorbance of $3 \mathrm{~mL}$ sample solution $+1 \mathrm{~mL}$ $\mathrm{DPPH}$ reagent, $A_{1}$ was the absorbance of $3 \mathrm{~mL}$ sample solution $+1 \mathrm{~mL}$ anhydrous ethanol, and $A_{0}$ was the absorbance of $1 \mathrm{~mL}$ DPPH solution+3 $\mathrm{mL}$ water.

2.3.3. Ferrous Ion Chelating Capacity [30]. $1 \mathrm{~mL}$ of PCP-Cs $(0.15-3.0 \mathrm{~g} / \mathrm{L})$ was mixed with $2.25 \mathrm{~mL}$ distilled water and $0.05 \mathrm{~mL} 2.0 \mathrm{mmol} / \mathrm{L}$ ferrous chloride solution, respectively, and the reaction lasts for $30 \mathrm{~s}$. Next, the solutions were mixed with $0.2 \mathrm{~mL} 5.0 \mathrm{mmol} / \mathrm{L}$ phenazine and reacted at room temperature for $10 \mathrm{~min}$, and the absorbance of the mixture was measured at $562 \mathrm{~nm}$. The experiment used water instead of polysaccharide solution and ferrous chloride solution as the blank group and control group.
EDTA-2Na was used as the positive control group. Lower absorbance indicated a stronger chelating capacity for ferrous ions. Each experiment was repeated three times.

Polysaccharide chelating ability $(\%)=\frac{\left[A_{0}-\left(A_{1}-A_{2}\right)\right]}{A_{0}} \times 100$,

where $A_{0}$ is the absorbance of the blank group, $A_{1}$ is the absorbance of the sample group, and $A_{2}$ is the absorbance of the control group.

\subsection{Regulation of CaOx Crystal Growth by PCP-Cs [31]}

2.4.1. CaOx Crystal Synthesis. CaOx metastable solution was carried out in a $50 \mathrm{~mL}$ volumetric flask by adding $3.0 \mathrm{~mL}$ of $10 \mathrm{mmol} / \mathrm{L} \mathrm{CaCl}_{2}$ and $1 \mathrm{~mL}$ of $0.50 \mathrm{~mol} / \mathrm{L} \mathrm{NaCl}$; then, add a certain amount of PCP-C solution to make the final concentrations of polysaccharide: $0.05,0.1,0.2,0.4$, and $0.8 \mathrm{~g} / \mathrm{L}$, add distilled water to about $45 \mathrm{~mL}$, then add $3.0 \mathrm{~mL}$ of $10 \mathrm{mmol} / \mathrm{L}$ $\mathrm{Na}_{2} \mathrm{Ox}$, and finally dilute volume to scale with distilled water. The solution thus obtained is $c\left(\mathrm{Ca}^{2+}\right)=c\left(\mathrm{Ox}^{2-}\right)=0.60$ $\mathrm{mmol} / \mathrm{L}$ and $c(\mathrm{NaCl})=10 \mathrm{mmol} / \mathrm{L}$. The crystal was filtered by a $0.22 \mu \mathrm{m}$ microporous membrane. The above $\mathrm{CaOx}$ solution was poured into a $50 \mathrm{~mL}$ beaker for crystallization, and a clean glass slide was placed at the bottom of the beaker. In order to prevent supersaturation of the system due to volatilization of solvent water from driving crystal formation, crystal growth was carried out at static conditions. After the crystal grows for $3 \mathrm{~d}$, the substrate was taken out and dried in a dryer. The concentration of soluble $\mathrm{Ca}^{2+}$ ions in the supernatant was measured through inductively coupled plasma (ICP) emission spectrometry.

The above synthesized $\mathrm{CaOx}$ crystals were characterized by Fourier infrared (FT-IR), field emission scanning electron microscope (SEM), X-ray diffraction (XRD), and Zeta potentiometer.

2.4.2. Characterization of SEM. The samples were treated with gold spray and observed under a field emission scanning electron microscope for morphology analysis.

2.4.3. Characterization of FT-IR. The dried CaOx sample (2.0 mg) was mixed with $\mathrm{KBr}(200 \mathrm{mg})$, followed by grinding with agate mortar, tableting, and scanning with an infrared spectrometer in the wavenumber range of $4000-400 \mathrm{~cm}^{-1}$.

2.4.4. Characterization of XRD. The synthesized crystals were analyzed in an X-ray diffractometer under the test conditions of $\mathrm{CuK} \alpha$ ray, graphite monochromator, $30 \mathrm{kV}, 25 \mathrm{~mA}$, scanning range of $5-60^{\circ}$, scanning speed of $8^{\circ} / \mathrm{min}$, and step width of $0.02 \%$ for qualitative and quantitative analyses.

The relative percentage contents of COM and COD in the $\mathrm{CaOx}$ precipitates were calculated through the $K$ value method [31] and the relative percentage contents of COD:

$$
\mathrm{COD} \%=\frac{I_{\mathrm{COD}}}{I_{\mathrm{COD}}+I_{\mathrm{COM}}},
$$


where $I_{\mathrm{COM}}$ and $I_{\mathrm{COD}}$ are the intensities of the spacing (101) of COM and (200) of COD crystals.

2.4.5. Zeta Potential Determination of the Crystal Surface. $\mathrm{CaOx}$ crystals $(1 \mathrm{mg})$ were dispersed in $3.0 \mathrm{~mL}$ of doubledistilled water. After ultrasonication for $10 \mathrm{~min}$, the Zeta potential was detected with a Zetasizer Nano ZS90 apparatus at $25^{\circ} \mathrm{C}$.

2.4.6. TGA for Determinating Polysaccharide Content in Crystals. According to Reference [26], the thermogravimetric analysis curves of $\mathrm{CaOx}$ crystals formed in the presence or absence of polysaccharides were measured by a Mettler Toledo thermal analyzer under a nitrogen atmosphere from $25^{\circ} \mathrm{C}$ to $900^{\circ} \mathrm{C}$ at a heating rate of $10^{\circ} \mathrm{C} / \mathrm{min}$. The polysaccharide content in the crystals was calculated from the thermal curves.

\subsection{Cell Experiments}

2.5.1. Cell Culture and Cytotoxicity Detection of PCP-Cs. HK2 cells were cultured in DMEM-F12 containing 10\% fetal bovine serum [32]. Cell suspension (density: $1 \times 10^{5}$ cells $/ \mathrm{mL}$ ) was inoculated into 96-well plates to make cells assemble into a monolayer; then, PCP-C0, PCP-C1, PCP$\mathrm{C} 2$, and PCP-C3 with final concentrations of 20, 40, 60, 80, and $100 \mu \mathrm{g} / \mathrm{mL}$ were added to cells, respectively. After $24 \mathrm{~h}$ culture, the cell viability was measured by CCK-8. Absorbance $(A)$ was measured at $450 \mathrm{~nm}$ by an enzyme reader according to the kit measurement method, and the cell viability rate was calculated. Each experiment was repeated in five parallel wells.

2.5.2. Cell Viability Detection [32]. After cells were confluent into the monolayer, the experiment was divided into 3 groups: (1) normal control group: only the serum-free culture medium was added; (2) damaged group: $2.8 \mathrm{mM}$ of sodium oxalate was added, and cells were damaged for $3.5 \mathrm{~h}$; and (3) protection group: PCP-C0, PCP-C1, PCP-C2, and PCP-C3 with final concentrations of 20, 40, 60, 80, and $100 \mu \mathrm{g} / \mathrm{mL}$ were added to preprotect cells for $12 \mathrm{~h}$, followed by $2.8 \mathrm{mM}$ oxalate injury for $3.5 \mathrm{~h}$. After incubating the above groups for $12 \mathrm{~h}$, add $10 \mu \mathrm{L}$ of the CCK- 8 reagent to each well and incubate at $37^{\circ} \mathrm{C}$ for $1.5 \mathrm{~h}$. Absorbance $(A)$ was measured by using the enzyme mark instrument at $450 \mathrm{~nm}$. Each experiment was repeated in five parallel wells. Cell viability was determined using the equation below.

2.5.3. Reactive Oxygen Species (ROS) Level Detection [32]. Cells were inoculated into 12 -well culture plates at concentrations of $1.0 \times 10^{5}$ cells $/ \mathrm{mL}$ and $1 \mathrm{~mL} /$ well. The experimental model and grouping were the same as the CCK- 8 experiment, and $100 \mu \mathrm{g} / \mathrm{mL}$ of PCP-Cs was used to protect the cells. The cells were stained with $2^{\prime}, 7^{\prime}$-dichlorodihydrofluorescein diacetate (DCFH-DA) at $37^{\circ} \mathrm{C}$ for $30 \mathrm{~min}$. The cells were washed with PBS three times to remove DCFHDA that did not enter the cells. The fluorescence intensity was observed under a fluorescence microscope and also detected by a microplate reader. Each experiment was repeated in three parallel wells.
2.5.4. Superoxide Dismutase (SOD) Activity Detection. SOD activity was assessed using a commercially available kit based on the autooxidation of hydroxylamine. The experimental model and grouping were the same as the CCK- 8 experiment, and $100 \mu \mathrm{g} / \mathrm{mL}$ of PCP-Cs was used to protect the cells. At the indicated time points, the treated cells were homogenized in $100 \mathrm{mmol} / \mathrm{L}$ Tris- $\mathrm{HCl}$ buffer and centrifuged at $10,000 \mathrm{rpm}$ for $20 \mathrm{~min}$, and then the SOD activity was determined using assay kits. The absorbance of the supernatant was then measured directly by a microplate reader at $560 \mathrm{~nm}$ with a reference wavelength of $600 \mathrm{~nm}$.

2.5.5. Malondialdehyde (MDA) Detection. For lipid peroxidation assay, we used a commercial kit to quantify the generation of MDA according to the manufacturer's protocol. The experimental model and grouping were the same as the CCK- 8 experiment, and $100 \mu \mathrm{g} / \mathrm{mL}$ of PCP-Cs was used to protect the cells. The cells were harvested by trypsinization, and cellular extracts were prepared by sonication in icecold buffer (50 mM Tris-HCl, $\mathrm{pH}=7.5,5 \mathrm{mM}$ EDTA, and $1 \mathrm{mM} \mathrm{DTT}$ ). After sonication, lysed cells were centrifuged at $10,000 \mathrm{rpm}$ for $20 \mathrm{~min}$ to remove debris. The supernatant was subjected to the measurement of MDA levels by detecting the absorbance at $532 \mathrm{~nm}$.

2.5.6. 8-Hydroxy-Deoxyguanosine (8-OHdG) Detection. 8OHdG is a commonly used marker of oxidative DNA damage. The experimental model and grouping were the same as the CCK- 8 experiment, and $100 \mu \mathrm{g} / \mathrm{mL}$ of PCP-Cs was used to protect the cells. The concentration of 8-OHdG was measured using a commercial ELISA kit according to the manufacturer's instructions. The color change is measured spectrophotometrically at a wavelength of $450 \mathrm{~nm}$.

2.6. Statistical Analysis. The normal distribution of experimental results was analyzed by the Shapiro-Wilk test. Data were assessed using a one-way ANOVA test, followed by Tukey's multiple comparison test for those following normal distribution. Experimental data were expressed by mean \pm standard deviation $(\bar{x} \pm \mathrm{SD})$. The data were presented as individual values and assessed using the Kruskal-Wallis test, followed by Dunn's multiple comparison test when following a nonnormal distribution. If $P<0.05$, there was a significant difference; if $P<0.01$, the difference was extremely significant; if $P>0.05$, there was no significant difference.

\section{Results}

\subsection{Carboxymethylation and Characterization of P. cocos Polysaccharide (PCP-CO)}

3.1.1. Polysaccharide Carboxymethylation. The carboxymethylation reaction belongs to bimolecular nucleophilic substitution (SN2) reactions [33]. First, the hydroxyl group of PCP-C0 was reacted with $\mathrm{NaOH}$ to form an alkoxide, and the carboxymethyl group was reacted with the alkoxide to form a carboxymethylated polysaccharide (PCP-C) (Figure 1). 


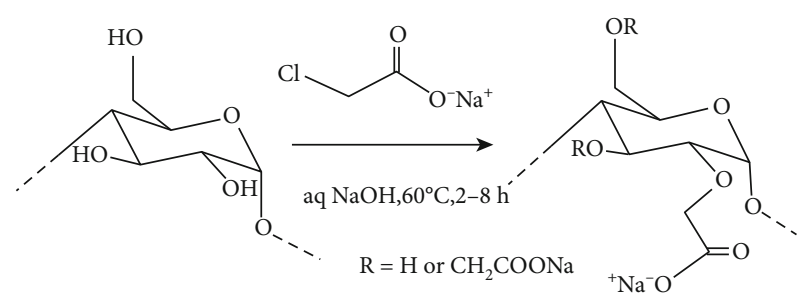

Figure 1: Carboxymethylation reaction of Poria cocos polysaccharide.

3.1.2. Detection of -COOH Content in PCP-Cs. The -COOH content in each carboxymethylated polysaccharide (PCP-C) was determined by conductometric titration. The titration curves are shown in Figure 2(a). The $-\mathrm{COOH}$ contents of PCP-C0, PCP-C1, PCP-C2, and PCP-C3 were $2.54 \%$, $6.13 \%, 10.24 \%$, and $16.22 \%$, respectively. After carboxymethylation modification, the molecular weight of the polysaccharide increased, but no obvious change in the molecular weight of the polysaccharide was detected [34].

3.1.3. FT-IR Characterization of PCP-Cs. Figure 2(b) shows the FT-IR spectra of PCP-Cs with different degrees of carboxymethylation. The strong absorption band at $3428.1 \mathrm{~cm}^{-}$ ${ }^{1}$ corresponds to the absorption peak of the stretching vibration of $-\mathrm{OH}$ in the polysaccharides. The absorption band at $2930.2 \mathrm{~cm}^{-1}$ corresponds to the stretching vibration of $\mathrm{C}-\mathrm{H}$. The peak at $1600 \mathrm{~cm}^{-1}$ corresponds to the stretching vibration of C-H-O and C-O bonds. The peak at $1428.6 \mathrm{~cm}^{-1}$ is the stretching vibration of the carboxyl group. Absorptions in the region of $1500-1000 \mathrm{~cm}^{-1}$ are attributed to epoxy vibration, $(\mathrm{COH})$ side group stretching vibration, and C-O-C glycosidic bond vibration [35]. The peak at $1032.4 \mathrm{~cm}^{-1}$ corresponds to the stretching vibration of the pyranose ring of glucose residues [19].

After carboxymethylation of PCP-C0, a new absorption peak appeared at $1326.5 \mathrm{~cm}^{-1}$, which belongs to the absorption peak of carboxymethyl $\left(-\mathrm{CH}_{2} \mathrm{COOH}\right)$. According to the carboxymethylation reaction (Figure 1), the substitution of $-\mathrm{CH}_{2} \mathrm{COOH}$ occurred on the $-\mathrm{OH}$ group of polysaccharides and manifested as a new absorption peak near $1326.5 \mathrm{~cm}^{-1}$, thereby confirming the successful carboxymethylation [36].

3.1.4. ${ }^{1} \mathrm{H} N M R$ Characterization of PCP-Cs. In the ${ }^{1} \mathrm{H}$ NMR spectrum of PCP-C0 (Figure 2(c)), $\delta 5.14,3.98,3.67,3.58$, 3.81 , and $3.66 \mathrm{ppm}$ belong to the signal peaks of $\mathrm{H}-1$ to $\mathrm{H}-6$ of $\alpha$-D-Gal; $\delta 4.95,3.59,3.98,3.89,4.08$, and 1.14 ppm belong to the signal peaks of H-1 to H-6 of $\alpha$-(1-6)-L-Fuc (Table 1); $\delta 4.95,3.88,3.75,3.89,4.08$, and $1.14 \mathrm{ppm}$ belong to the signal peaks of $\mathrm{H}-1$ to $\mathrm{H}-6$ of $\alpha$-(1-3)-L-Fuc; $\delta 4.71 \mathrm{ppm}$ corresponds to the signal peak of $\mathrm{H}-1$ of $\beta$-(1-3)-D-Glc; and $\delta 4.59 \mathrm{ppm}$ corresponds to the signal peak of $\mathrm{H}-1$ of $\beta$-(13)-D-Gal $[37,38]$. Compared with that of PCP-C0, the ${ }^{1} \mathrm{H}$ NMR of the carboxymethylated polysaccharide PCP-C1 showed no new strong signal peaks (Figure 2(d)).

3.1.5. ${ }^{13} \mathrm{C} N M R$ Characterization of PCP-Cs. In the ${ }^{13} \mathrm{C} N M R$ spectrum of PCP-C0 (Figure 2(e)), the strong signals at $\delta 102.53,74.12,95.89,69.58,75.74$, and $60.75 \mathrm{ppm}$ belong to the C-1 to C-6 signal peaks of $\beta$-(1-3)-D-Glc (Table 2); $\delta 103.7,73.5,86.9,69.1,77.0$, and $61.6 \mathrm{ppm}$ belong to the C1 to C-6 signal peaks of $\beta$-(1-3)-D-Gal; $\delta 73.6,67.0,70.5$, and $61.3 \mathrm{ppm}$ belong to the C-3 to C-6 signal peaks of $\alpha$-DGal; $\delta 98.2,67.7,70.5,71.6,67.3$, and $15.8 \mathrm{ppm}$ belong to the C-1 to C-6 signal peaks of $\alpha$-(1-6)-L-Fuc; and $\delta 98.2,67.0$, $69.7,71.6,67.3$, and 15.8 ppm belong to the C-1 to C-6 signal peaks of $\alpha$-(1-3)-L-Fuc [19, 37].

The main signals in the ${ }^{13} \mathrm{C}$ NMR spectrum of PCP-C1 were 102.8 (C-1), 79.2 (C-3), 74.8 (C-5), 73.1 (C-2), 69.6 (C-4), 60.9 (C-6), and 177.8 ppm (C-7) (Figure 2(f)). The signals at 71.2 and $73.1 \mathrm{ppm}$ are assigned to the methylene carbon atom by the carboxymethyl substituent. The signal increased at $70.6 \mathrm{ppm}$ and decreased at $60.7 \mathrm{ppm}$, indicating the occurrence of carboxymethyl substitution at the C-6 position [36, 37]. For the ${ }^{13} \mathrm{C}$ NMR of the carboxymethylated polysaccharide PCP-C1, a new signal peak appeared at $177.8 \mathrm{ppm}$, which belongs to the $\mathrm{C}=\mathrm{O}$ bond of the carboxymethyl group $\left(-\mathrm{CH}_{2} \mathrm{COOH}\right)$; this finding can be used as evidence of the carboxymethylation reaction, consistent with previous reports $[23,36]$.

\subsection{Antioxidant Capacity of PCP-Cs}

3.2.1. Scavenging Capacity of $\mathrm{OH}$ Radicals. $\mathrm{OH}$ radicals can cause tissue damage and cell death and lead to many diseases [39]. Therefore, scavenging $\mathrm{OH}$ radicals is one of the important characteristics of the antioxidant defense mechanism. As shown in Figure 3(a), as the concentration of PCP-Cs increased, the ability to remove $\mathrm{OH}$ increased. At the same concentration, the higher the carboxymethylation degree is, the stronger the polysaccharide will be.

3.2.2. DPPH Radical Scavenging Capacity. The DPPH radical has a characteristic absorption peak at $517 \mathrm{~nm}$. When $\mathrm{DPPH}$ is reduced to the nonfree radical form DPPH-H by an antioxidant, the purple color of the $\mathrm{DPPH}$ radical fades, resulting in a decrease in absorbance [40]. The DPPH radical scavenging ability of PCP-Cs also has a concentration-dependent effect (Figure 3(b)), and PCPC3 with the highest degree of carboxymethylation has the strongest scavenging ability.

3.2.3. Chelating Effect on Ferrous Ions. Transition metal ions, such as $\mathrm{Fe}^{2+}$ and $\mathrm{Cu}^{2+}$, can catalyze the chain reaction and generate free radicals, leading to cell oxidative damage [30]. Chelating off metal ions can interrupt chain reaction and prevent oxidative damage. Given that $\mathrm{Fe}^{2+}$ has high activity, the ability to chelate this ion is often used to evaluate the antioxidant ability of polysaccharides. As shown in Figure 3(c), when the concentration is $3 \mathrm{~g} / \mathrm{L}$, the chelating ability levels of PCP-C0, PCP-C1, PCP-C2, and PCP$\mathrm{C} 3$ to $\mathrm{Fe}^{2+}$ are $46.9 \%, 51.5 \%, 61.9 \%$, and $63.7 \%$, respectively, and PCP-C3 has the strongest chelating ability.

The three experimental results mentioned above indicate that the carboxymethylation modification of the original PCP-C0 enhances the antioxidant capacity of the polysaccharide. 


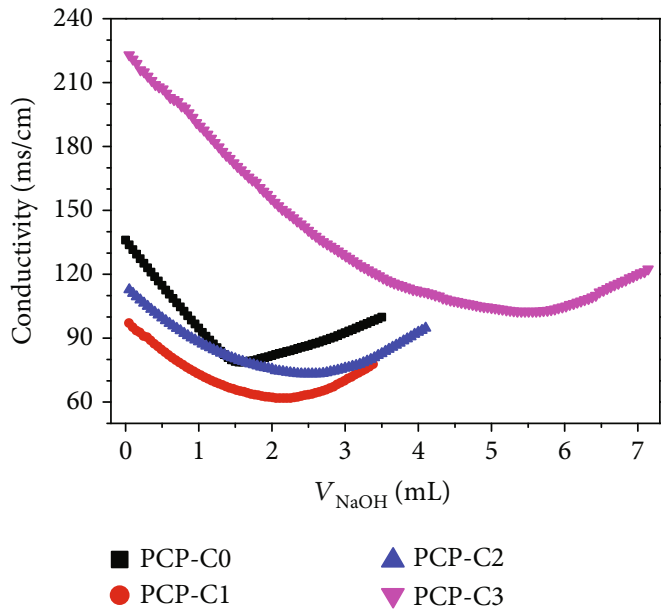

(a)

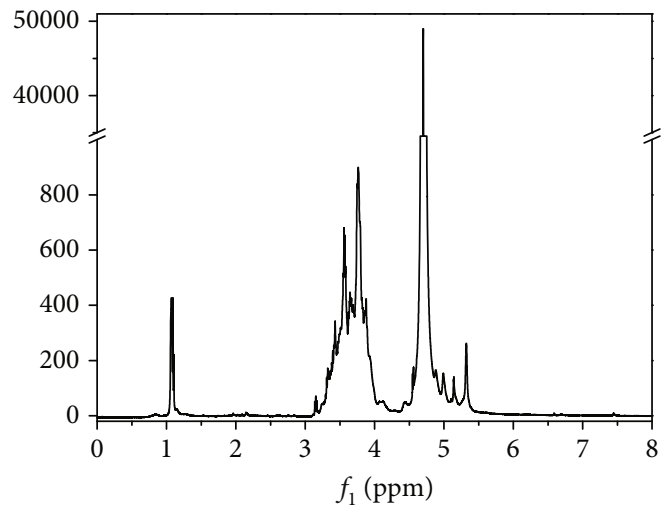

(c)

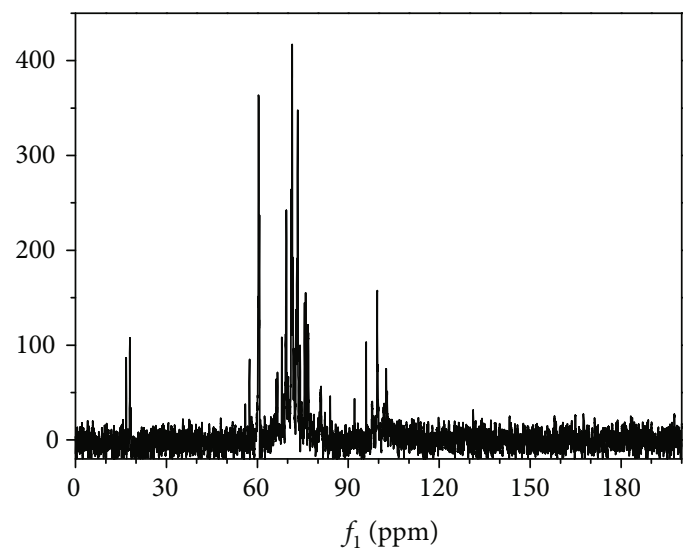

(e)

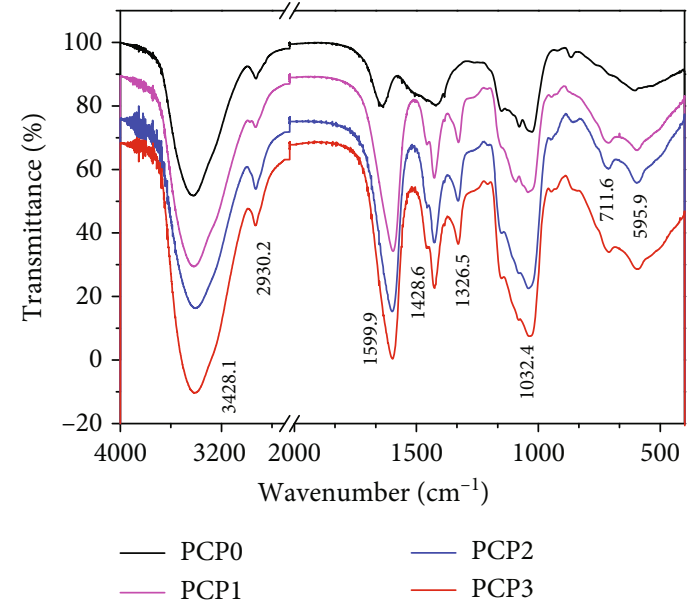

(b)

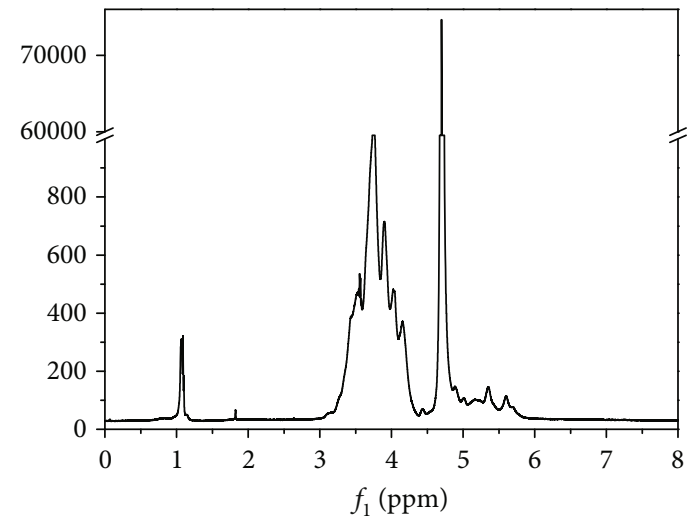

(d)

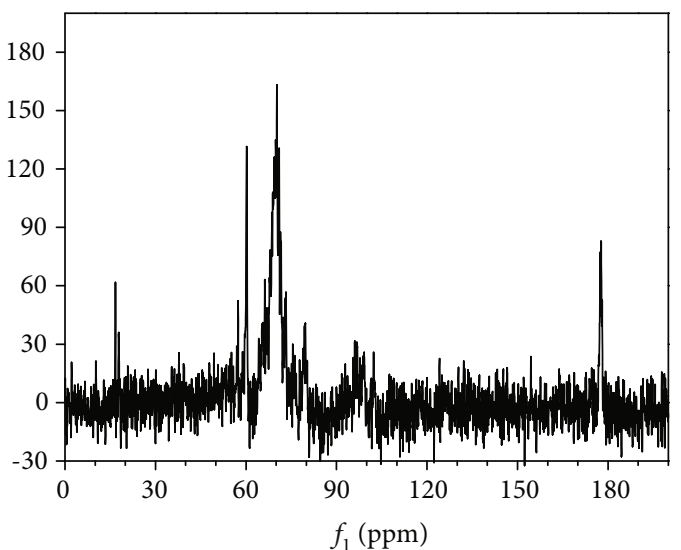

(f)

Figure 2: Characterization of PCP-Cs. (a) Titration curves for detecting -COOH content in four polysaccharides, $c(\mathrm{PCP}-\mathrm{Cs})=0.10 \mathrm{~g} / \mathrm{L}$ and $c(\mathrm{NaOH})=5.24 \mathrm{mmol} / \mathrm{L}$. (b) FT-IR spectra of four polysaccharides. $(\mathrm{c}, \mathrm{d}){ }^{1} \mathrm{H}$ NMR spectra of PCP-C0 and PCP-C1. (e, f) ${ }^{13} \mathrm{C} \mathrm{NMR} \mathrm{spectra} \mathrm{of}$ PCP-C0 and PCP-C1.

\subsection{Characterization of the CaOx Crystal Structure} Induced by PCP-Cs

3.3.1. XRD Characterization. The effects of four kinds of PCP-Cs with different - $\mathrm{COOH}$ contents on the formation of $\mathrm{CaOx}$ crystals were studied. Figure 4(a) shows the XRD patterns of $\mathrm{CaOx}$ crystals formed in the presence of $0.4 \mathrm{~g} / \mathrm{L}$ PCP-Cs. The diffraction peaks at crystal plane spacing $d=$ $0.593,0.364,0.296$, and $0.235 \mathrm{~nm}$ belong to the $(\overline{1} 01),(020)$ , (202), and (130) crystal planes of calcium oxalate 
TABLE 1: Chemical shifts corresponding to the ${ }^{1} \mathrm{H}$ NMR spectrum of carboxymethylated polysaccharide PCP-C0.

\begin{tabular}{|c|c|c|c|c|c|c|c|}
\hline \multirow{2}{*}{$\begin{array}{l}\text { Polysaccharide } \\
\text { type }\end{array}$} & \multirow{2}{*}{$\begin{array}{l}\text { Sugar } \\
\text { residue }\end{array}$} & \multicolumn{6}{|c|}{${ }^{1} \mathrm{H}$ chemical shift (ppm) } \\
\hline & & $\mathrm{H}-1$ & $\mathrm{H}-2$ & $\mathrm{H}-3$ & $\mathrm{H}-4$ & H-5 & H-6 \\
\hline \multirow{5}{*}{ PCP-C0 } & $\begin{array}{c}\beta-(1-3)-D- \\
\text { Glc }\end{array}$ & 4.71 & - & - & - & - & - \\
\hline & $\begin{array}{c}\beta-(1-3)-D- \\
\text { Gal }\end{array}$ & 4.59 & - & - & - & - & - \\
\hline & $\alpha-\mathrm{D}-\mathrm{Gal}$ & 5.14 & 3.98 & 3.67 & 3.58 & 3.81 & 3.66 \\
\hline & $\begin{array}{l}\alpha-(1-6)-\mathrm{L}- \\
\quad \text { Fuc }\end{array}$ & 4.95 & 3.59 & 3.98 & 3.89 & 4.08 & 1.14 \\
\hline & $\begin{array}{l}\alpha-(1-3)-\mathrm{L}- \\
\text { Fuc }\end{array}$ & 4.95 & 3.88 & 3.75 & 3.89 & 4.08 & 1.14 \\
\hline
\end{tabular}

monohydrate (COM), respectively. The peaks at $d=0.617$, $0.441,0.277$, and $0.224 \mathrm{~nm}$ belong to the diffraction peaks of (200), (211), (411), and (213) crystal planes of calcium oxalate dihydrate (COD), respectively [41].

Quantitative calculations according to the $K$ value method $[12,26]$ indicated that as the $-\mathrm{COOH}$ content of PCP-Cs increases, the percentage of COD in the crystals induced by PCP-Cs gradually increases (Figure 4(b)). The percentages of COD induced by $0.4 \mathrm{~g} / \mathrm{L}$ PCP-C 0 , PCP-C 1 , PCP-C2, and PCP-C3 were 45.7\%, 76.4\%, 82.7\%, and 100\%, respectively.

With PCP-C1 as a representative, the regulatory effect of polysaccharide concentration on $\mathrm{CaOx}$ crystal formation was studied (Figure 5(a)). In the absence of the polysaccharide, only the diffraction peaks of COM appeared. The addition of polysaccharides induced the formation of COD. With increasing PCP-C1 concentration, the intensity of the diffraction peak attributed to COD in the crystal increased continuously, indicating that the percentage of COD induced by the polysaccharide increased. Quantitative calculation also showed that in the presence of $0.05,0.1,0.2,0.4$, and $0.8 \mathrm{~g} / \mathrm{L}$ PCP-C1, the contents of COD in the formed CaOx crystals were $15.4 \%, 37.4 \%, 48.4 \%, 74.7 \%$, and $100 \%$, respectively (Figure 5(b)).

3.3.2. FT-IR Characterization. FT-IR detection further supported the regulatory effect of $\mathrm{PCP}-\mathrm{Cs}$ on $\mathrm{CaOx}$ crystal formation (Figure 6(a)). In the absence of the polysaccharide, the following peaks were obtained: carbonyl asymmetric stretching vibration $v_{\mathrm{as}}\left(\mathrm{COO}^{-}\right)$in the $\mathrm{CaOx}$ crystal at $1620 \mathrm{~cm}^{-1}$, symmetric stretching vibration $v_{\mathrm{s}}\left(\mathrm{COO}^{-}\right)$at $1316 \mathrm{~cm}^{-1}$, and stretching vibration peaks at $3492-3062 \mathrm{~cm}$ ${ }^{1}$, which belong to the $\mathrm{O}-\mathrm{H}$ bond of the crystal water. This finding indicated that the calcium oxalate formed is the pure COM crystal [42].

After PCP-Cs were added, $v_{\text {as }}\left(\mathrm{COO}^{-}\right)$and $v_{\mathrm{s}}\left(\mathrm{COO}^{-}\right)$in the spectrogram undergo a blue shift in different degrees with increasing - $\mathrm{COOH}$ content in PCP-Cs (Figure 6(b)). In particular, $v_{\text {as }}\left(\mathrm{COO}^{-}\right)$gradually shifts from $1624 \mathrm{~cm}^{-1}$ to $1644 \mathrm{~cm}^{-1}$ and $v_{\mathrm{s}}\left(\mathrm{COO}^{-}\right)$gradually shifts from $1320 \mathrm{~cm}^{-1}$ to $1329 \mathrm{~cm}^{-1}$, indicating that the COM percentage in the $\mathrm{CaOx}$ crystal continuously decreases, while the COD percentage gradually increases. Given that the $v_{\mathrm{as}}\left(\mathrm{COO}^{-}\right)$and $v_{\mathrm{s}}(\mathrm{CO}$
$\left.\mathrm{O}^{-}\right)$of COD are 1644 and $1329 \mathrm{~cm}^{-1}$ [41, 43], respectively, the blue shift values of $v_{\mathrm{as}}\left(\mathrm{COO}^{-}\right)$and $v_{\mathrm{s}}\left(\mathrm{COO}^{-}\right)$depend on the percentage of COD in the mixture.

In the fingerprint region, the absorption bands of $\mathrm{COD}$ crystals were found at 922 and $622 \mathrm{~cm}^{-1}$, which differ from those of $\operatorname{COM}\left(959,887\right.$, and $\left.667 \mathrm{~cm}^{-1}\right)$, of which 887 and $667 \mathrm{~cm}^{-1}$ belong to COM C-C stretching vibration and O$\mathrm{C}-\mathrm{O}$ in-plane bending vibration, respectively [43].

Figure 7(a) shows the FT-IR spectra of $\mathrm{CaOx}$ crystals formed in the presence of $\mathrm{PCP}-\mathrm{C} 1$ at different concentrations. As the PCP-C1 concentration increased from $0.05 \mathrm{~g} / \mathrm{L}$ to $0.8 \mathrm{~g} / \mathrm{L}, v_{\mathrm{as}}\left(\mathrm{COO}^{-}\right)$and $v_{s}\left(\mathrm{COO}^{-}\right)$are continuously blue-shifted (Figure $7(\mathrm{~b}))$, where $v_{\text {as }}\left(\mathrm{COO}^{-}\right)$increased from $1619 \mathrm{~cm}^{-1}$ to $1644 \mathrm{~cm}^{-1}$ and $v_{\mathrm{s}}\left(\mathrm{COO}^{-}\right)$increased from $1316 \mathrm{~cm}^{-1}$ to $1329.5 \mathrm{~cm}^{-1}$. The higher the concentration of $\mathrm{PCP}-\mathrm{C} 1$ is, the higher the percentage of COD in the induced $\mathrm{CaOx}$ crystals will be.

3.4. Regulation of PCP-Cs on CaOx Morphology. Figure 8(a) shows the SEM images of $\mathrm{CaOx}$ crystals formed in the presence of different PCP-Cs. In the absence of the polysaccharide, most of the crystals formed were COM crystals (Figure 4(a)), which have sharp edges and high aggregation degrees. After adding $0.4 \mathrm{~g} / \mathrm{L}$ PCP-Cs, COD crystals were formed. With increasing carboxymethylation degrees in PCP-Cs, not only the content of COD increased but also the shape of COD gradually changed from the usual tetragonal bipyramid shape to a round and blunt straw hat shape; meanwhile, the COD induced by PCP-C3 is disc-shaped.

The morphology of $\mathrm{CaOx}$ crystals formed by adjusting PCP-C1 concentration is shown in Figure 8(b). With the concentration of PCP-C1 increasing from $0.05 \mathrm{~g} / \mathrm{L}$ to $0.8 \mathrm{~g} / \mathrm{L}$, the proportion of COD in the crystals gradually increased, and the crystal became rounder and blunter, the crystal surface became smoother, and the crystal dispersivity was improved.

3.5. Effect of PCP-Cs on the Zeta Potential of Crystals. The particle surface with a high charge density has a large absolute value of the Zeta potential and electrostatic repulsion force between particles, it cannot easily aggregate, and it is stable in solution [43]. The Zeta potentials of $\mathrm{CaOx}$ crystals generated by different PCP-Cs are shown in Figure 9(a). With the $-\mathrm{COOH}$ content in PCP-Cs increasing from $2.54 \%$ to $6.13 \%, 10.24 \%$, and $16.22 \%$, the Zeta potential decreased from $-4.66 \mathrm{mV}$ to $-5.82 \mathrm{mV},-8.35 \mathrm{mV}$, and $-12.7 \mathrm{mV}$; i.e., the higher the - $\mathrm{COOH}$ content of polysaccharides is, the larger the absolute value of the Zeta potential on the surface of the $\mathrm{CaOx}$ crystal induced. This finding indicated that the more negatively charged PCP-C molecular weight was adsorbed on the crystal surface. For the same polysaccharide $\mathrm{PCP}-\mathrm{C} 1$, the absolute value of the Zeta potential increased with increasing concentration (Figure 9(b)).

3.6. PCP-C Increases Soluble $\mathrm{Ca}^{2+}$ Concentration and Decreases $\mathrm{CaOx}$ Precipitation. As shown in Figure 10(a), the molar amount of $\mathrm{CaOx}$ precipitates $(n(\mathrm{CaOx})=9.8-17.7 \mu \mathrm{mol})$ generated in the presence of different PCP-Cs is lower than that of the blank group 
TABLE 2: Chemical shifts corresponding to ${ }^{13} \mathrm{C}$ NMR spectra of carboxymethylated polysaccharides (PCP-Cs).

\begin{tabular}{|c|c|c|c|c|c|c|c|c|c|}
\hline \multirow{2}{*}{ Polysaccharide type } & \multirow{2}{*}{ Sugar residue } & \multicolumn{8}{|c|}{${ }^{13} \mathrm{C}$ chemical shift (ppm) } \\
\hline & & C-1 & $\mathrm{C}-2$ & $\mathrm{C}-3$ & C-4 & C-5 & C-6 & $-\mathrm{CH}_{3}$ & C-7 \\
\hline \multirow{5}{*}{ PCP-C0 } & $\beta-(1-3)-D-G l c$ & 102.53 & 74.12 & 95.89 & 69.58 & 75.74 & 60.75 & - & - \\
\hline & $\beta-(1-3)-\mathrm{D}-\mathrm{Gal}$ & 103.7 & 73.5 & 86.9 & 69.1 & 77.0 & 61.6 & - & - \\
\hline & $\alpha$-D-Gal & - & - & 73.6 & 67.0 & 70.5 & 61.3 & - & - \\
\hline & $\alpha-(1-6)-\mathrm{L}-\mathrm{Fuc}$ & 98.2 & 67.7 & 70.5 & 71.6 & 67.3 & - & 15.8 & - \\
\hline & $\alpha$-(1-3)-L-Fuc & 98.2 & 67.0 & 69.7 & 71.6 & 67.3 & - & 15.8 & - \\
\hline PCP-C1 & & 102.8 & 73.1 & 79.2 & 69.6 & 74.8 & 60.9 & - & 177.8 \\
\hline
\end{tabular}

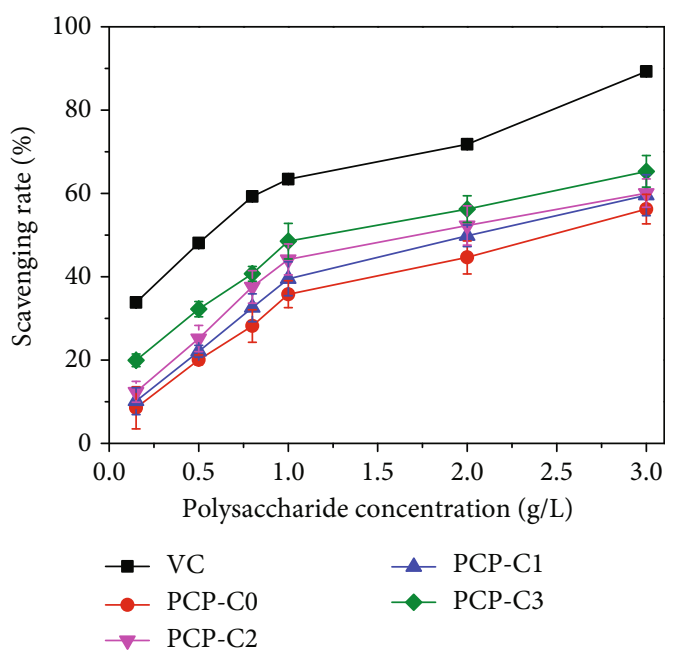

(a)

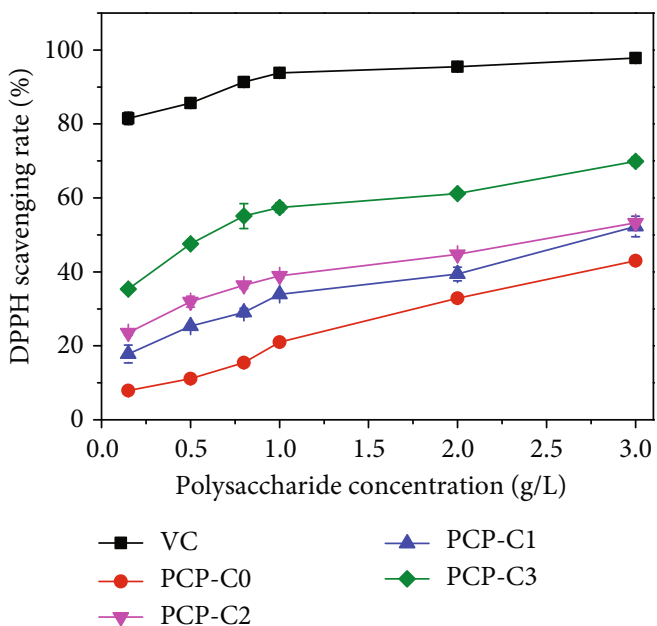

(b)

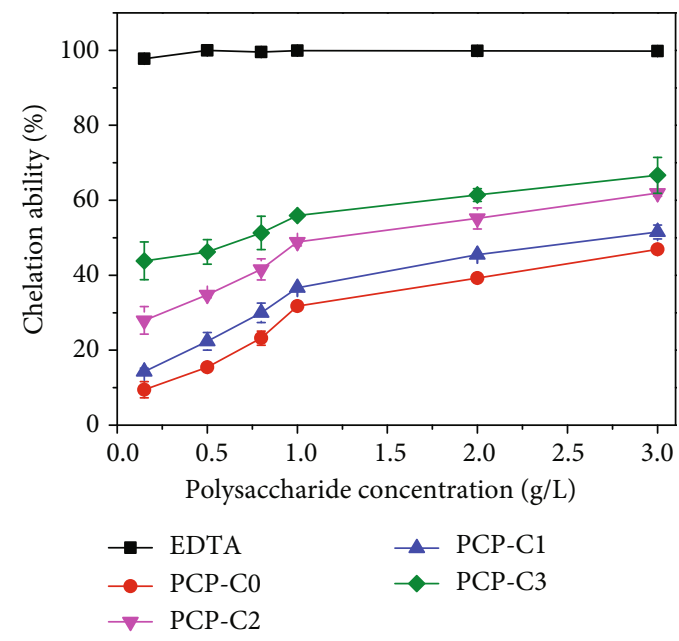

(c)

Figure 3: Antioxidant activity of different carboxymethylated Poria cocos polysaccharides (PCP-Cs). (a) PCP-C scavenging ability of OH radicals. (b) PCP-C scavenging ability of DPPH. (c) PCP-C chelating ability of $\mathrm{Fe}^{2+}$.

$(22.5 \mu \mathrm{mol})$, and $m(\mathrm{CaOx})$ in the presence of PCP-C3 is the least $(9.8 \mu \mathrm{mol})$. In the presence of different PCP-Cs, the concentration of soluble $\mathrm{Ca}^{2+}$ ions $\left(c\left(\mathrm{Ca}^{2+}\right)=26.5 \sim 43.1 \mu \mathrm{mol} / \mathrm{L}\right.$ ) in the supernatant is greater than that in the blank group $(16.5 \mu \mathrm{mol} / \mathrm{L})$ (Figure 10(b)). The higher the content of - $\mathrm{COOH}$ in the polysaccharide is, the greater the $c\left(\mathrm{Ca}^{2+}\right)$ in the supernatant will be.
To verify the reliability of the results in Figure 10, we calculated the sum of the molar amount of soluble $\mathrm{Ca}^{2+}$ in the supernatant $\left(n\left(\mathrm{Ca}^{2+}\right)\right)$ and the molar amount of $\mathrm{Ca}^{2+}$ in CaOx precipitates $\left(n\left(\mathrm{Ca}^{2+}\right)\right)$ (Table 3$)$. The obtained total molar amount of $\mathrm{Ca}^{2+}$ ions in each group is $30.7 \sim 33.1 \mu \mathrm{mol}$, which is consistent with the total molar amount of calcium in the reactant $(30.0 \mu \mathrm{mol})$. 


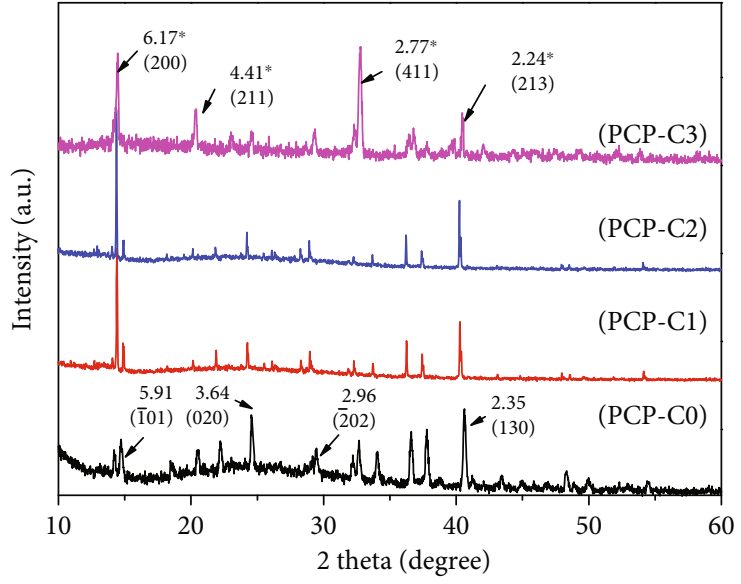

(a)

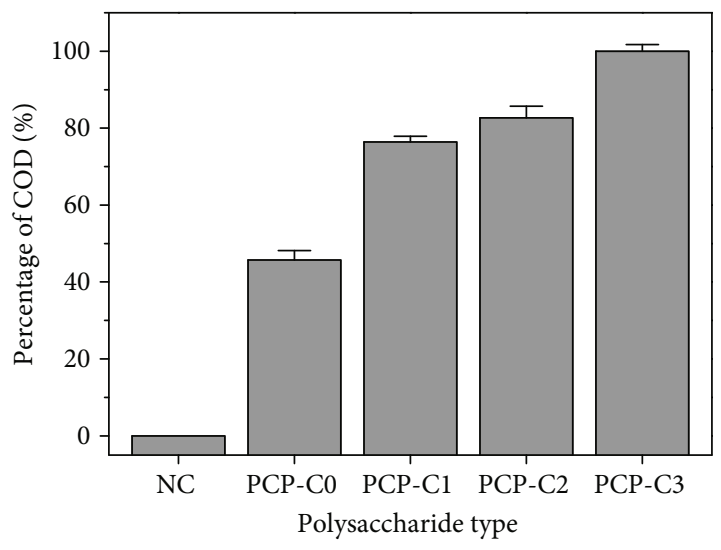

(b)

Figure 4: XRD spectrum (a) and COD percentage content (b) of the CaOx crystal formed by PCP-Cs with different COOH contents. (A) PCP-C0. (B) PCP-C1. (C) PCP-C2. (D) PCP-C3. Polysaccharide concentration: $0.4 \mathrm{~g} / \mathrm{L}$.

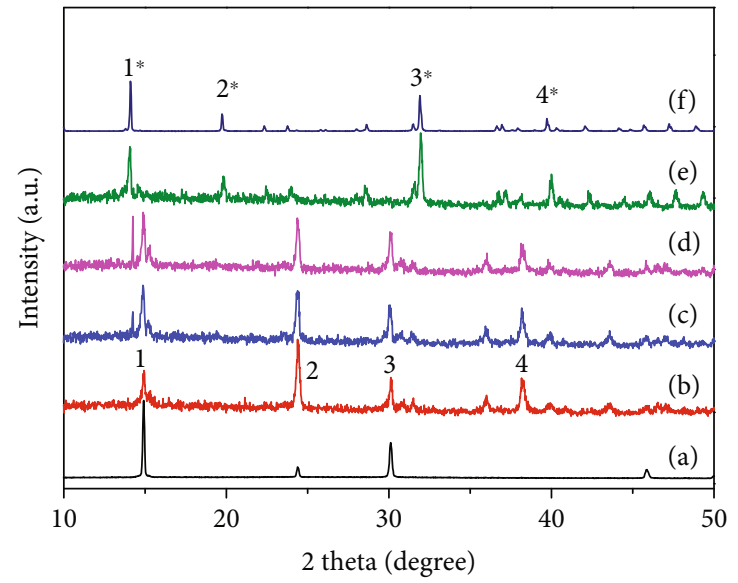

(a)

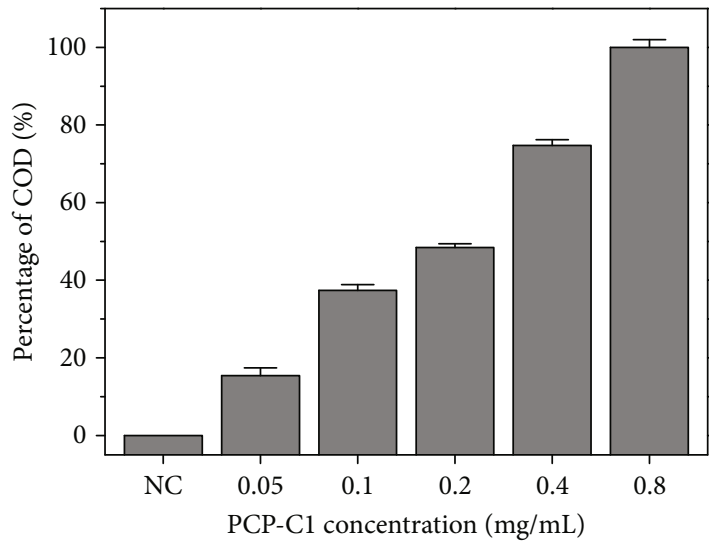

(b)

Figure 5: XRD spectrum (a) and COD percentage content (b) of the CaOx crystal formed in the presence of PCP-C1 with different concentrations. (A) 0 , (B) 0.05, (C) 0.1, (D) 0.2, (E) 0.4, and (F) $0.8 \mathrm{~g} / \mathrm{L}$. The peaks of $1,2,3$, and 4 belong to (101), (020), (202), and (130 ) crystal planes of COM crystals at $d=0.593,0.364,0.296$, and $0.235 \mathrm{~nm}$, respectively. The peaks of $1^{*}, 2^{*}, 3^{*}$, and $4^{*}$ belong to $(200)$, ( $211),(411)$, and (213) crystal faces of COD crystals at $d=0.618,0.442,0.278$, and $0.224 \mathrm{~nm}$, respectively.

3.7. Thermogravimetric Analysis of CaOx Crystals. As shown in Figure 11, the decomposition of $\mathrm{CaOx}$ crystals obtained in the blank group without the polysaccharide is divided into three steps, and the weight loss percentages were $12.18 \%$ (stage A), 8.33\% (stage C), and 28.99\% (stage D), consistent with the theoretical weight loss values of $12.33 \%, 19.17 \%$, and $30.12 \%$ of $\mathrm{COM}\left(\mathrm{CaC}_{2} \mathrm{O}_{4} \cdot \mathrm{H}_{2} \mathrm{O}\right)$ decomposed into $\mathrm{CaC}_{2} \mathrm{O}_{4}, \mathrm{CaCO}_{3}$, and $\mathrm{CaO}[44]$.

However, the TGA curve of the $\mathrm{CaOx}$ crystal formed after adding $0.4 \mathrm{~g} / \mathrm{L}$ PCP-C1 differed from that of the blank group due to the formation of COD crystals induced by PCP-C1 and the incorporation of PCP-C1 by the crystal. The $\mathrm{CaOx}$ crystals induced by the polysaccharides lose free water and crystalline water at $25^{\circ} \mathrm{C} \sim 128^{\circ} \mathrm{C}$ (section A). When the temperature continues to rise to $200^{\circ} \mathrm{C} \sim 400^{\circ} \mathrm{C}$ (section $\mathrm{B})$, the polysaccharide molecules adsorbed on the crystals will undergo thermal decomposition [45]. When the temperature reaches $741^{\circ} \mathrm{C}$ (section $\mathrm{E}$ ), the $\mathrm{CaOx}$ sample was basically decomposed, and the weight percentages of the final residue of $\mathrm{CaOx}$ crystals regulated by PCP-C0, PCP-C1, PCP-C2, and PCP-C3 were $28.72 \%, 29.60 \%, 30.95 \%$, and $31.16 \%$, respectively.

The crystals obtained in the blank group without polysaccharides showed no thermogravimetric loss at $200^{\circ} \mathrm{C} \sim 400^{\circ} \mathrm{C}$ (stage B), while the crystals induced by PCP-Cs underwent thermal decomposition; as such, the weight loss at this stage can be considered to be polysaccharide loss [45], that is, the weight of the polysaccharide incorporated into the crystal. Based on stage B in Figure 11, the proportions of PCP-C0, PCP-C1, PCP-C2, and PCP-C3 incorporated into the crystal were $20.52 \%, 15.60 \%, 10.65 \%$, and $9.78 \%$, respectively, and the decomposition temperatures were $205.10^{\circ} \mathrm{C}, 212.00^{\circ} \mathrm{C}$, 


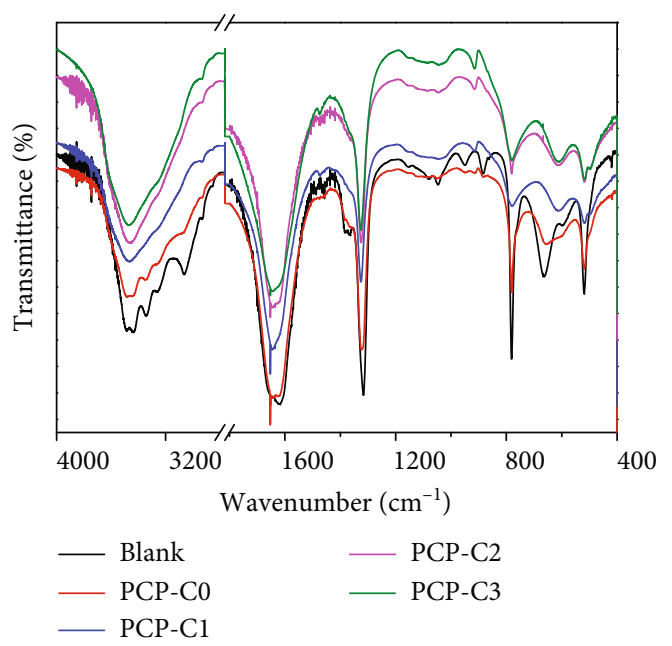

(a)

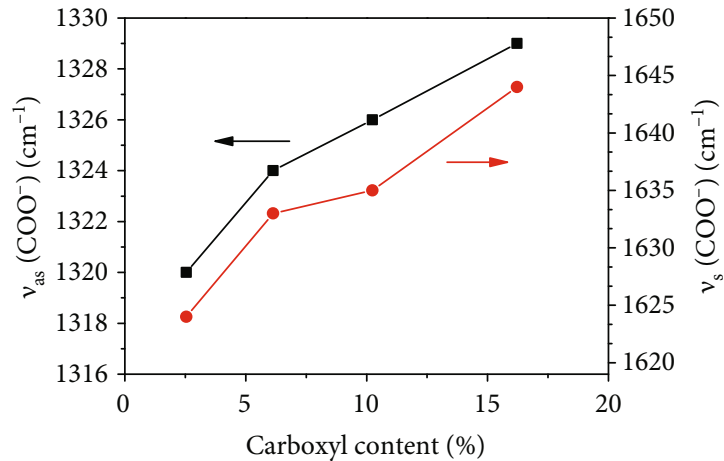

(b)

FIGURE 6: FT-IR spectrum (a) and change of the main absorption peak wavenumber (b) of CaOx crystals generated by regulation in the presence of PCP-Cs with different $-\mathrm{COOH}$ contents. $c(\mathrm{CaOx})=0.6 \mathrm{mmol} / \mathrm{L}$.

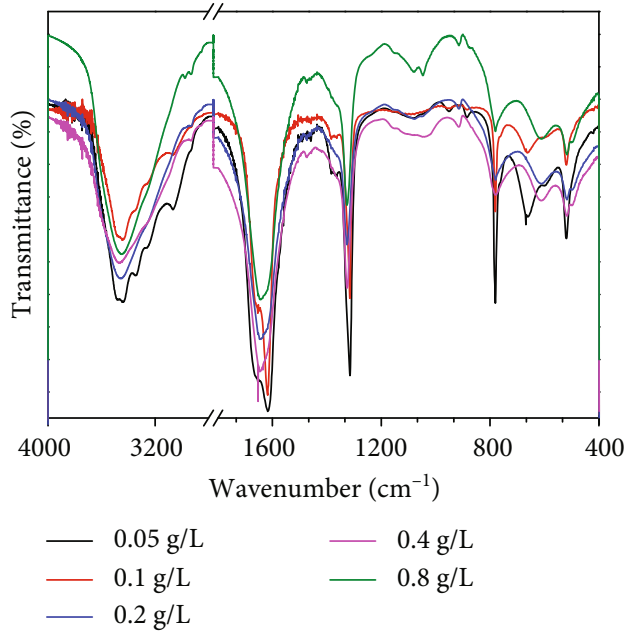

(a)

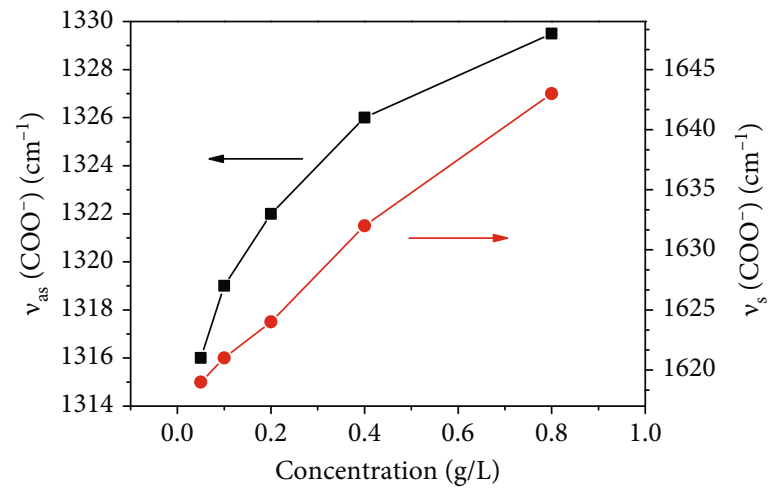

(b)

FIGURE 7: FT-IR spectrum (a) and change of the main absorption peak wavenumber (b) of CaOx crystals generated by regulation in the presence of PCP-C1 with different concentrations. $c(\mathrm{CaOx})=0.6 \mathrm{mmol} / \mathrm{L}$.

$212.67^{\circ} \mathrm{C}$, and $212.05^{\circ} \mathrm{C}$, respectively. PCP-C3, which has the highest degree of carboxymethylation, has the lowest proportion of incorporation into the crystals and has a higher decomposition temperature than the original PCP, indicating that PCP-C3 has a stronger specific interaction with the crystals and stronger binding. Given that the incorporation of PCPCs makes the decomposition temperature of the "PCP-C crystal" sample higher than that of the pure COM sample, the stability of the "PCP-C crystal" during heating is higher than that of pure crystals without the polysaccharide.

3.8. Toxicity Assessment of PCP-Cs on HK-2 Cells. The CCK-8 method was used to detect the toxicity of PCP-Cs with different -COOH contents on HK-2 cells (Figure 12(a)). After HK2 interacted with PCP-Cs for $24 \mathrm{~h}$, the cell viability was above $100 \%$. Hence, PCP-Cs caused no cytotoxicity on HK-2 cells and promoted cell growth.
3.9. PCP-C Protects HK-2 Cells from Damage. Figure 12(b) shows the changes in $\mathrm{HK}-2$ cell viability before and after preprotection with different carboxymethylated PCP-Cs. After $2.8 \mathrm{mM}$ oxalate oxidation injury, the cell activity decreased from $100 \%$ of the control group to $56.6 \%$. However, with different concentrations of PCP-C preprotection, the cell viability of the injured group was significantly higher than that of the injured group.

For the same polysaccharide with concentration $<100 \mu$ $\mathrm{g} / \mathrm{L}$, the preprotection of PCP-Cs shows a concentration effect; i.e., the higher the concentration of PCP-Cs is, the better the protection effect will be.

At the same concentration, the cell viability of different polysaccharide protection groups followed the order of PCP$\mathrm{C} 0<\mathrm{PCP}-\mathrm{C} 1<\mathrm{PCP}-\mathrm{C} 2<\mathrm{PCP}-\mathrm{C} 3$; i.e., $\mathrm{PCP}-\mathrm{C} 3$ with the highest $-\mathrm{COOH}$ content had the best protection effect. At $100 \mu \mathrm{g} / \mathrm{L}$, the cell activity under PCP-C3 protection reached $90.3 \%$. 

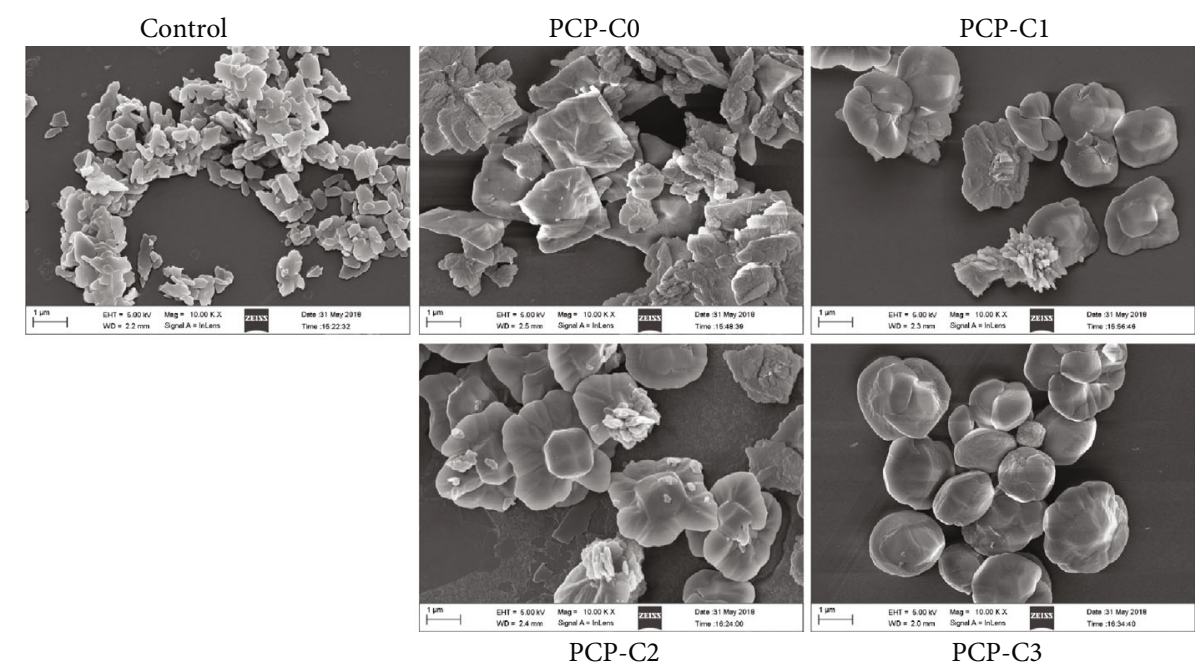

(a)
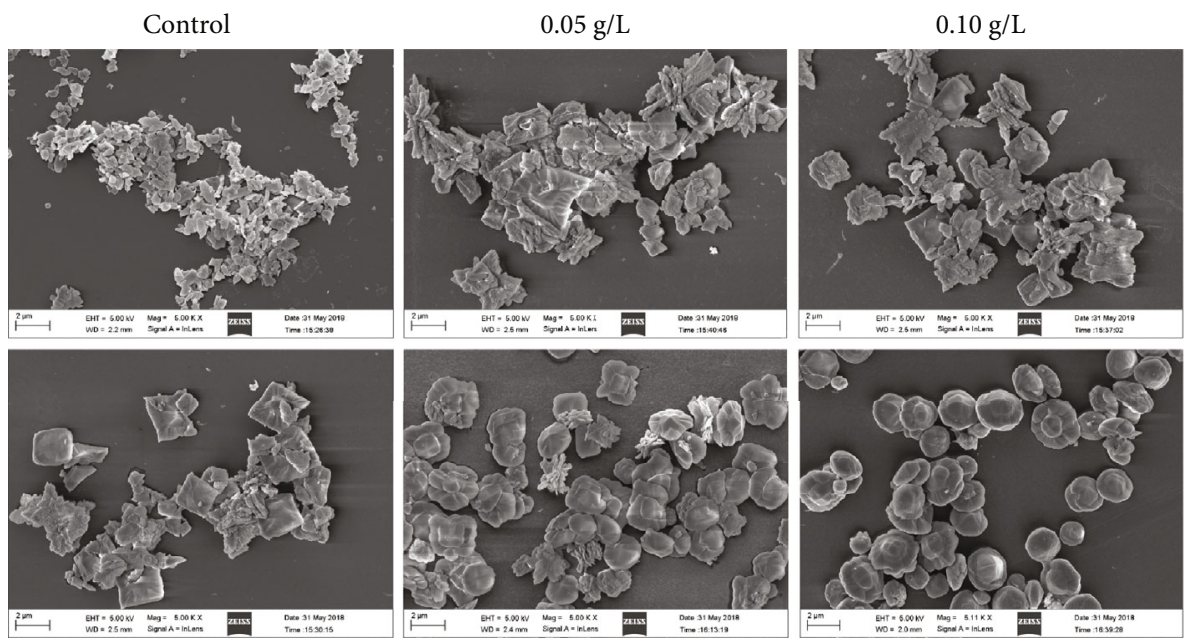

$0.20 \mathrm{~g} / \mathrm{L}$
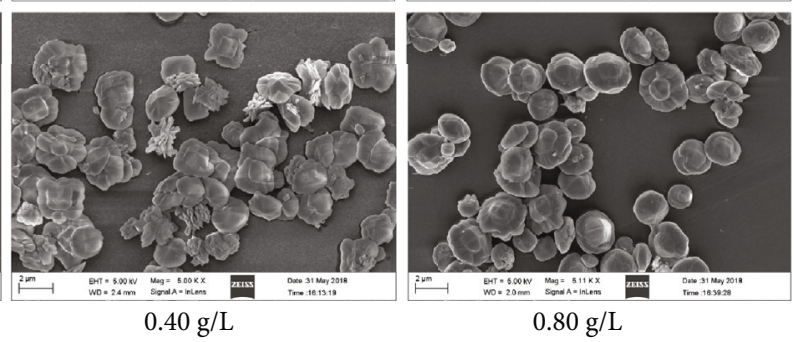

(b)

FIGURE 8: SEM image of the CaOx crystal formed by regulation of PCP-Cs. (a) Effects of -COOH content in PCP-Cs on CaOx morphology. (b) Effects of PCP-C1 concentration on CaOx morphology. (a) (A) PCP-C0, (B) PCP-C1, (C) PCP-C2, and (D) PCP-C3. Polysaccharide concentration: $0.4 \mathrm{~g} / \mathrm{L}$. (b) (A) 0, (B) 0.05, (C) 0.1, (D) 0.2, (E) 0.4, and (F) $0.8 \mathrm{~g} / \mathrm{L}$.

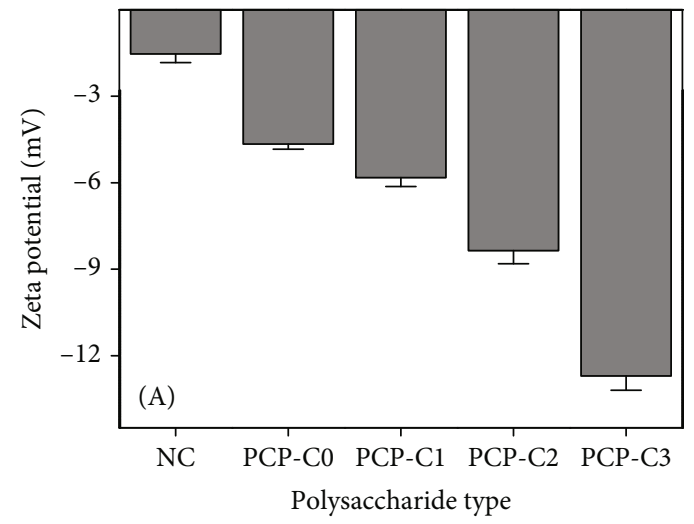

(a)

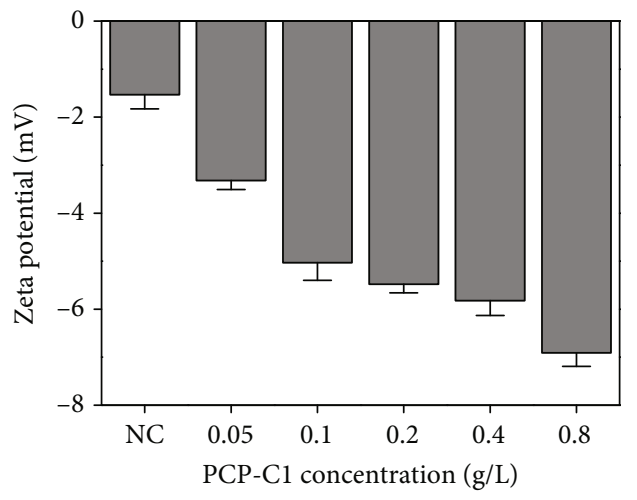

(b)

Figure 9: Zeta potential of the formed CaOx crystal regulated by PCP-Cs. (a) Effect of -COOH content of PCP-Cs on the Zeta potential. (b) Effect of PCP-C1 concentration on the Zeta potential. 


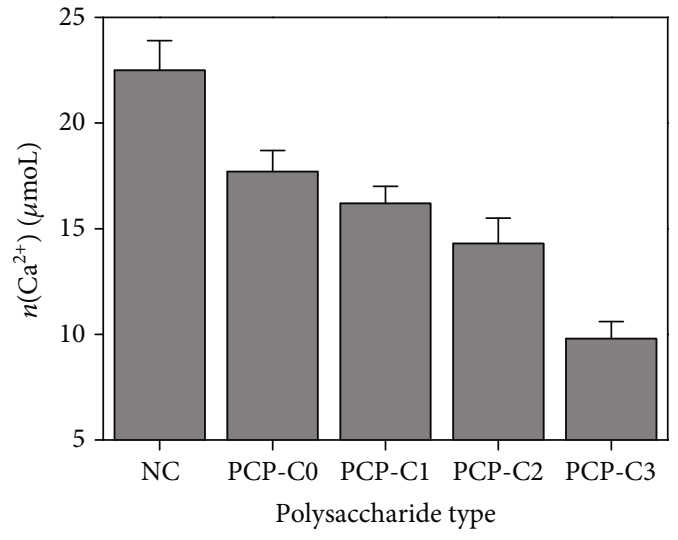

(a)

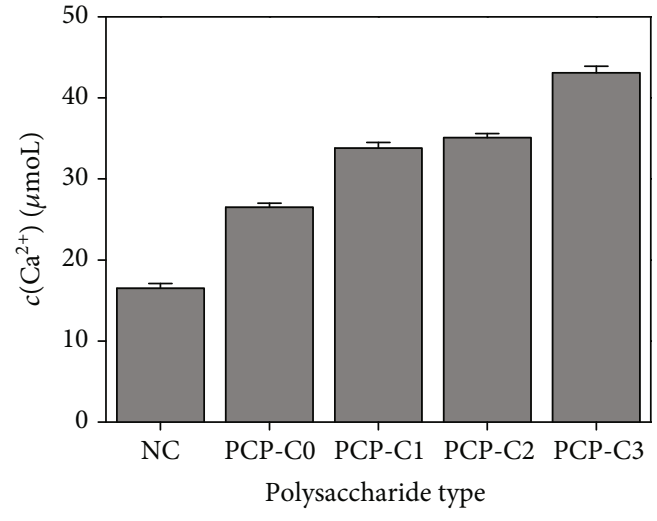

(b)

Figure 10: Effect of - $\mathrm{COOH}$ content of polysaccharides on the molar amount of $\mathrm{CaOx}$ precipitation and concentration of soluble $\mathrm{Ca}^{2+}$ in the supernatant. (a) Molar amount of CaOx precipitation. (b) Soluble calcium ion concentration. $c$ (PCP-Cs) $=0.4 \mathrm{~g} / \mathrm{L}$.

TABle 3: Effect of PCP-Cs on the CaOx crystal phase, soluble $\mathrm{Ca}^{2+}$ ion concentration in solution, and CaOx precipitation mass.

\begin{tabular}{lccccccc}
\hline Polysaccharide & $\begin{array}{c}\text { Carboxyl content } \\
(\%)\end{array}$ & $\begin{array}{c}\text { COD percentage } \\
(\%)\end{array}$ & $\begin{array}{c}c\left(\mathrm{Ca}^{2+}\right) \\
(\mu \mathrm{mol} / \mathrm{L})\end{array}$ & $\begin{array}{c}n\left(\mathrm{Ca}^{2+}\right) \\
(\mu \mathrm{mol})\end{array}$ & $\begin{array}{c}\text { Mass of CaOx } \\
(\mathrm{g})\end{array}$ & $\begin{array}{c}m(\mathrm{CaOx})^{*} \\
(\mu \mathrm{mol})\end{array}$ & $\begin{array}{c}\mathrm{Total} \mathrm{Ca}^{2+} \\
(\mu \mathrm{mol})\end{array}$ \\
\hline Blank & - & 0 & 16.5 & 8.2 & 0.00328 & 22.5 & 30.7 \\
PCP-C0 & 2.54 & 45.7 & 26.5 & 13.3 & 0.00274 & 17.7 & 30.9 \\
PCP-C1 & 6.13 & 76.4 & 33.8 & 16.9 & 0.00256 & 16.2 & 33.1 \\
PCP-C2 & 10.24 & 82.7 & 35.1 & 17.5 & 0.00226 & 14.3 & 31.9 \\
PCP-C3 & 16.22 & 100 & 43.1 & 21.6 & 0.00160 & 9.8 & 31.4 \\
\hline
\end{tabular}

${ }^{*}$ When calculating the precipitation mass of $\mathrm{CaOx} m(\mathrm{CaOx})$, the crystal waters in $\mathrm{COM}$ and $\mathrm{COD}$ should be considered; that is, the molar mass of $\mathrm{COM}$ and COD is 146 and $164 \mathrm{~g} / \mathrm{mol}$, respectively.

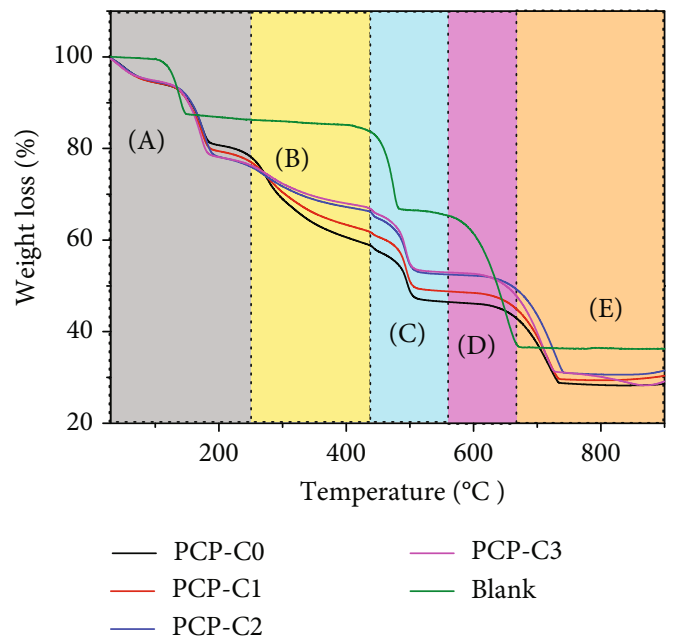

FIgURE 11: Thermogravimetric analysis curves of $\mathrm{CaOx}$ crystals formed in the presence of $0.4 \mathrm{~g} / \mathrm{L}$ PCP-Cs, respectively.

3.10. PCP-C Protection Reduces Reactive Oxygen Species (ROS) Production Caused by Oxalate. Figure 13(a) shows the ROS level changes in HK-2 cells before and after PCP$\mathrm{C}$ preprotection. In the normal group, the cells grew tightly, with the lowest ROS fluorescence intensity, that is, less ROS. The intensity of ROS fluorescence in cells damaged by oxalate was significantly enhanced. After $100 \mu \mathrm{g} / \mathrm{mL}$ of four
PCP-Cs was preprotected, the fluorescence intensity of ROS in cells became weak, which was between the normal group and the protection group (Figure 13(b)), indicating that PCP-Cs can resist oxidative damage from oxalate after protection.

At the same time, the preprotection effect of PCP-C1 with different concentrations on $\mathrm{HK}-2$ cells was also detected by a microplate reader (Figure 13(c)). With the increase of PCP-C1 concentration, the ROS level of cells gradually decreased, indicating that PCP-C1 has a concentration effect when protecting cells.

3.11. PCP-C Protection Increases Antioxidant Ability and Reduces Oxidative Damage. The reduction of SOD activity in the organism implies decreased ability to resist free radical-induced damage in the organism. The SOD activity in the oxalate-damaged group was decreased to $28.78 \pm$ $4.02 \%$ of the control value. After the protection by PCP-C0, PCP-C1, PCP-C2, and PCP-C3, the SOD activity increased to $49.22 \%, 64.78 \%, 74.57 \%$, and $84.18 \%$, respectively (Figure 14(a)).

The change of MDA content usually reveals the level of lipid peroxidation in vivo and indirectly reflects the degree of cell injury. After oxalate was used to damage the cells, the MDA content increased to $222.84 \%$ of the control group. The MDA content was obviously reduced in the PCP-Cprotected groups; the released content was reduced to 


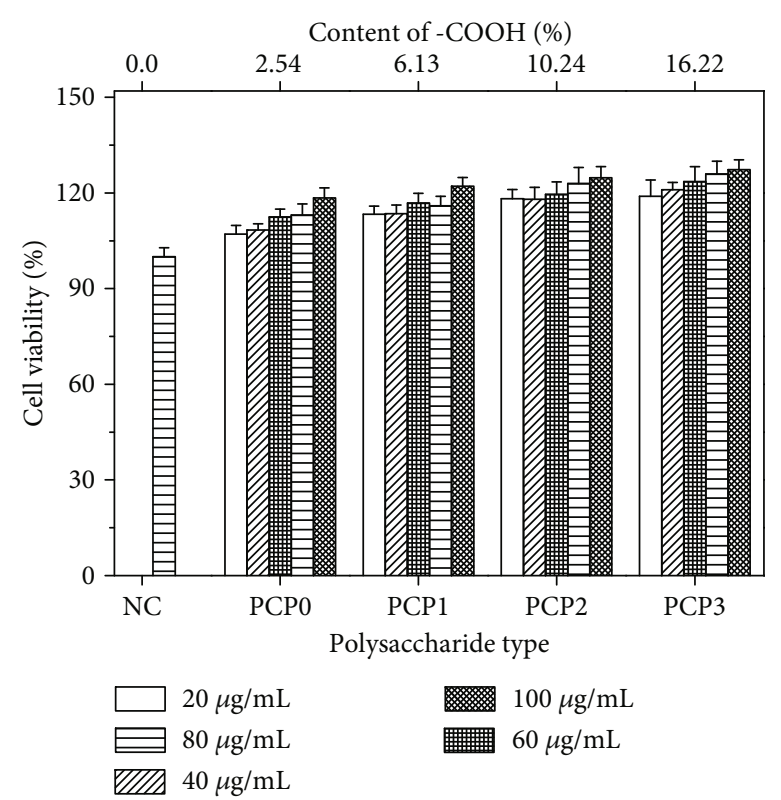

(a)

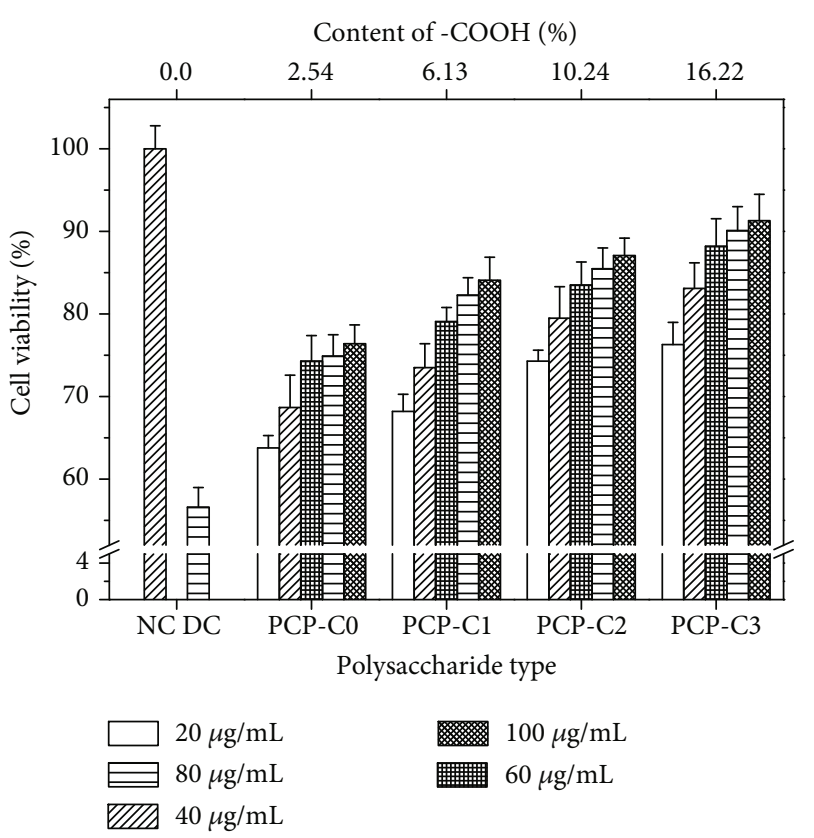

(b)

Figure 12: CCK-8 method to detect HK-2 cell viability. (a) Cytotoxicity of PCP-Cs with different concentrations. (b) The viability of HK-2 cells damaged by oxalate with or without PCP-C protection. NC: normal control group; DC: injury control group. Oxalate concentration: $2.8 \mathrm{mM}$. Injury time: $3.5 \mathrm{~h}$. Protection time: $12 \mathrm{~h}$. Compared with the injury group: ${ }^{*} P<0.05 ;{ }^{* *} P<0.01$.

197.97\% (PCP-C0), 164.84\% (PCP-C1), 132.68\% (PCP-C2), and $117.65 \%$ (PCP-C3) of the control group (Figure 14(b)). $\mathrm{PCP}-\mathrm{C} 3$ with the highest $-\mathrm{COOH}$ contents has the strongest ability to inhibit MDA release.

The concentration of 8-OHdG is considered a marker of oxidative DNA damage. The 8-OHdG expression was low in the normal control cells $(80.65 \mathrm{pg} / \mathrm{mL})$. In the oxalatedamaged group, the 8-OHdG expression obviously increased to $223.61 \mathrm{pg} / \mathrm{mL}$. The expression level of $8-\mathrm{OHdG}$ in the PCP-C-protected groups obviously decreased compared to the oxalate-damaged group. The 8-OHdG concentration decreased to $195.31-130.25 \mathrm{pg} / \mathrm{mL}$ (Figure 14(c)). PCP-C3 with the highest $-\mathrm{COOH}$ contents presented the optimum DNA protection ability.

\section{Discussion}

\subsection{Carboxymethylation Modification of $P$. cocos Polysaccharide}

4.1.1. Influence of Reaction Conditions. Carboxymethylation of PCP-C0 includes two steps. Firstly, $\mathrm{NaOH}$ reacts with -OH of polysaccharide molecules to generate alkoxide groups on the PCP-C0; then, the carboxymethyl group was formed in polysaccharide alkoxide and monochloroacetic acid $\left(\mathrm{ClCH}_{2} \mathrm{COOH}\right)$ by SN2 reaction $[14,15]$. The factors that affect the degree of substitution of polysaccharide carboxymethylation include reactant concentration, temperature, and reaction time (Table 4). In this experiment, three carboxymethylated polysaccharides PCP-C1, PCP-C2, and PCP-C3 were obtained at $60^{\circ} \mathrm{C}$ by changing the reaction time and reactant concentration. The contents of $-\mathrm{COOH}$ were
$6.13 \%, 10.24 \%$, and $16.22 \%$, respectively, which were greater than $2.54 \%$ of the initial polysaccharide PCP-C0. Duan et al. [33] carboxymethylated the natural polysaccharide RNP extracted from blackcurrant fruits. As the temperature increased from $50^{\circ} \mathrm{C}$ to $70^{\circ} \mathrm{C}$, the substitution degree increased from 0.57 to 1.10 , which may be due to the increased temperature enhancing the solubility of polysaccharide alkoxide, resulting in better contact between polysaccharide alkoxide and $\mathrm{ClCH}_{2} \mathrm{COOH}$. When the temperature increased further, the substitution degree decreased, which is attributed to the fact that too high a temperature is conducive to the occurrence of side reactions. Liu et al. [46] modified Sarcandra glabra polysaccharide by carboxymethylation and found that with the extension of reaction time, the degree of carboxymethylation first increased and then decreased. Prolonging the reaction time helps polysaccharides to expand and promote $\mathrm{ClCH}_{2} \mathrm{COOH}$ to enter the polysaccharide molecules. However, too long reaction time at higher temperatures is conducive to the formation of side reaction products, such as glycolate.

\subsubsection{Structural Identification of Carboxymethylated} Polysaccharides. From ${ }^{1} \mathrm{H}$ NMR and ${ }^{13} \mathrm{C}$ NMR spectra (Figure 2), PCP-C0 was composed of glucose, galactose, and fucose, and the main polysaccharide residues were $\alpha$ D-Gal, $\alpha$-(1-6)-L-Fuc, $\alpha$-(1-3)-L-Fuc, $\beta$-(1-3)-D-Glc, and $\beta$ (1-3)-D-Gal, which was basically consistent with the structure reported by Meikuang et al. [47] and Wang et al. [19]. After carboxymethylation, the ${ }^{13} \mathrm{C}$ NMR of PCP-C1 showed a new absorption peak at $177.8 \mathrm{ppm}$, which showed the characteristic absorption peak of the carboxymethyl group $\left(-\mathrm{CH}_{2} \mathrm{COOH}\right)[23,48]$. 

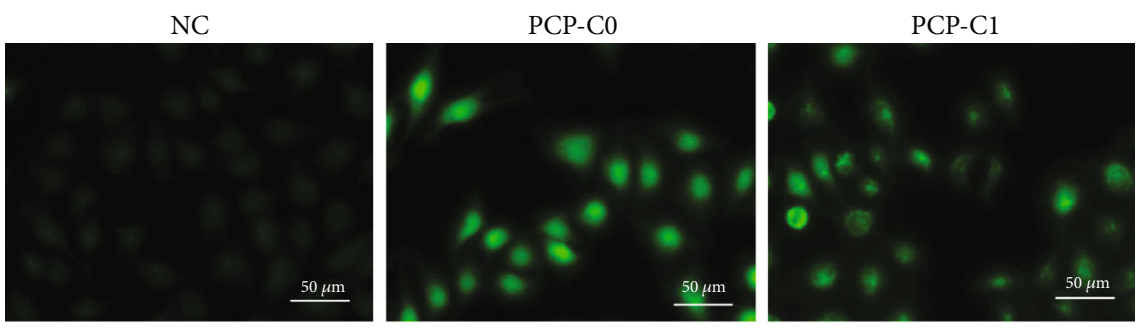

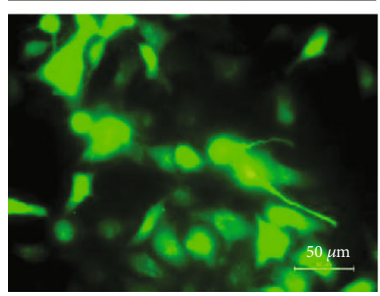

DC

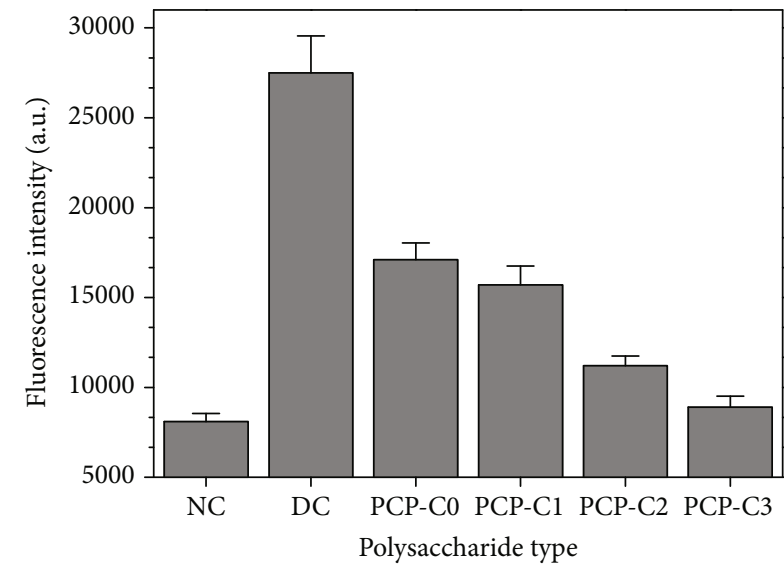

(b)

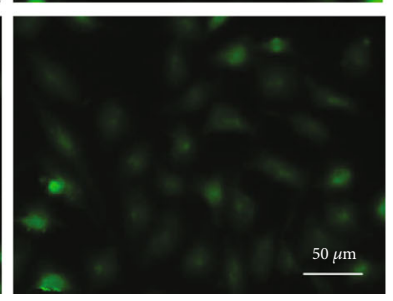

PCP-C2

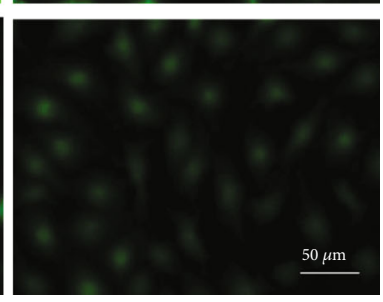

PCP-C3

(a)

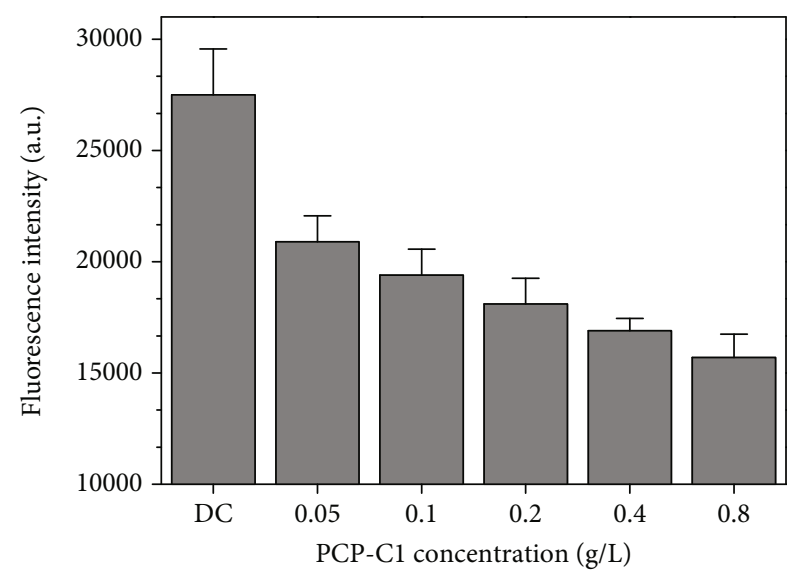

(c)

Figure 13: Effects of PCP-Cs before and after protection on ROS expression in HK-2 cells. (a, b) Effects of COOH content in PCP-Cs. Polysaccharide concentration: $100 \mu \mathrm{g} / \mathrm{mL}$. (c) Effect of PCP-C1 concentration. NC: normal control group; DC: injury control group. Oxalate concentration: $2.8 \mathrm{mM}$. Injury time: $3.5 \mathrm{~h}$. Protection time: $12 \mathrm{~h}$.

FT-IR spectra show that the main chain structures of the four carboxymethylated polysaccharides are similar, but the carboxymethylated polysaccharides have a new characteristic absorption peak at $1326.5 \mathrm{~cm}^{-1}$, which is attributed to $-\mathrm{CH}_{2} \mathrm{COOH}$ groups. The experimental results are consistent with the ${ }^{13} \mathrm{C}$ NMR results.

\subsubsection{Enhancement of Antioxidant Activity of} Polysaccharides after Carboxymethylation. Carboxymethylation modification can enhance the antioxidant activity of polysaccharide, which is related to the following factors:

(1) The introduction of the substituent group $-\mathrm{CH}_{2} \mathrm{COOH}$ changes the configuration of polysaccharide, which weakens the dissociation energy of hydrogen bonds in polysaccharide molecules [49] and improves the hydrogen supply capacity of polysaccharide

(2) The biological activity of polysaccharides is positively correlated with their water solubility. Carboxymethy- lation modification can increase the water solubility of polysaccharides [50], so the degree of freedom of polysaccharides is increased, and the ability to exert activity is stronger

(3) Polysaccharides have two mechanisms for antioxidant activity. One is that polysaccharides inhibit the generation of free radicals by chelating transition metal ions (such as $\mathrm{Fe}^{2+}$ and $\mathrm{Cu}^{2+}$ ions) $[51,52]$. The other is that polysaccharides can provide single electrons or hydrogen atoms for free radicals, thus terminating free radical chain reaction and achieving the purpose of scavenging free radicals. As the content of $-\mathrm{COOH}$ in carboxymethylated polysaccharide increases significantly, its ability to chelate transition metal ions and provide single electron or hydrogen atoms all increases, thereby increasing the antioxidant activity

Shi et al. [34] extracted the original crude Enteromorpha prolifera polysaccharide (PE) with a molecular weight of 


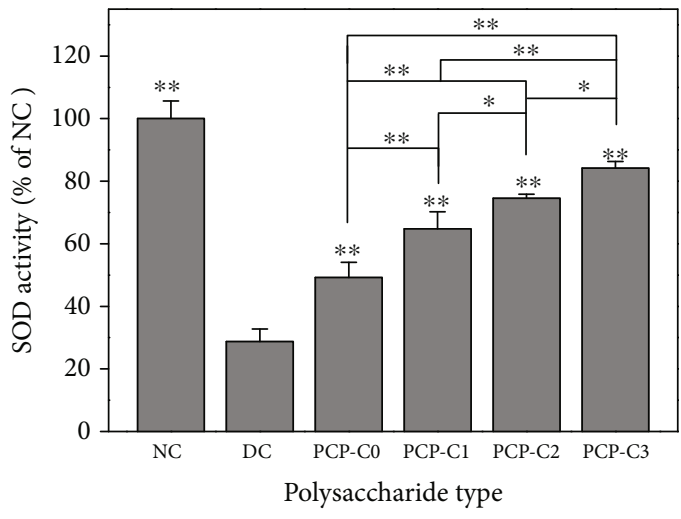

(a)

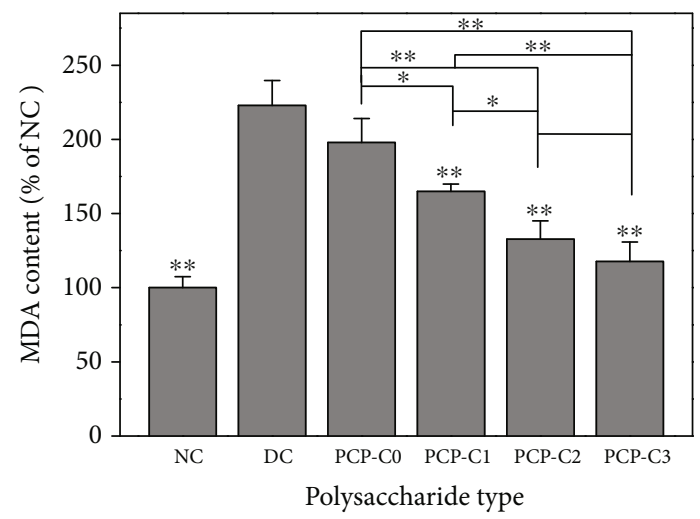

(b)

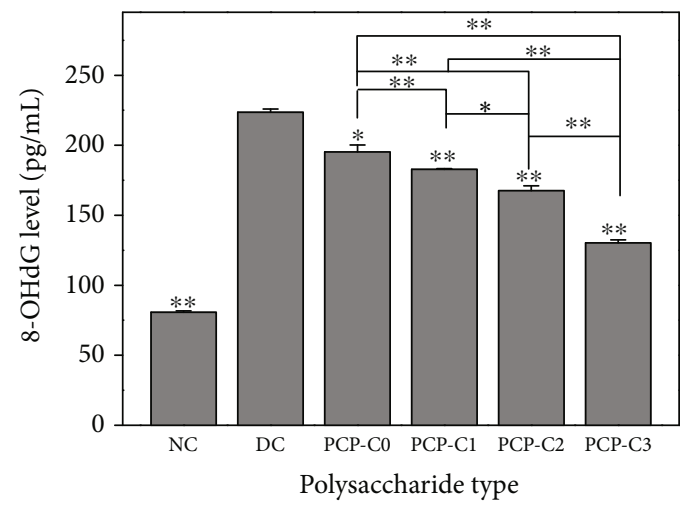

(c)

FIgURE 14: Effects of PCP-Cs before and after protection on SOD activity (a), MDA content (b), and 8-OHdG expression (c) in HK-2 cells. NC: normal control group; DC: injury control group. Oxalate concentration: $2.8 \mathrm{mM}$. Injury time: $3.5 \mathrm{~h}$. Protection time: $12 \mathrm{~h}$. Compared with the injury group: ${ }^{*} P<0.05 ;{ }^{* *} P<0.01$.

TABLE 4: Carboxymethylation conditions of PCP-Cs and carboxyl content of polysaccharides.

\begin{tabular}{lccccc}
\hline $\begin{array}{l}\text { Polysaccharide } \\
\text { type }\end{array}$ & $\begin{array}{c}\text { Isopropanol volume } \\
(\mathrm{mL})\end{array}$ & $\begin{array}{c}\mathrm{NaOH} \text { volume } \\
(\mathrm{mL})\end{array}$ & $\begin{array}{c}\text { Chloroacetic acid } \\
\text { amount }(\mathrm{g})\end{array}$ & $\begin{array}{c}\text { Reaction time } \\
(\mathrm{h})\end{array}$ & $\begin{array}{c}\text { Temperature } \\
\text { COOH content } \\
(\%)\end{array}$ \\
\hline PCP-C0 & - & - & - & - & 2 \\
PCP-C1 & 15 & 10 & 2.63 & 2.54 & 60 \\
PCP-C2 & 15 & 10 & 2.63 & 8 & 60 \\
PCP-C3 & 10 & 15 & 6.00 & 4 & 60 \\
\hline
\end{tabular}

$1400 \mathrm{kDa}$, degraded it to obtain a low molecular weight polysaccharide DPE with a molecular weight of $44 \mathrm{kDa}$, and carboxymethylated the DPE to obtain CDPE. The DPPH scavenging ability, hydroxyl radical scavenging ability, and reducing ability of the three polysaccharides are $\mathrm{CDPE}>\mathrm{D}$ PE $>$ PE. Li et al. [53] also showed that the radical scavenging ability and total antioxidant ability of the carboxymethylated degraded Sargassum fusiforme polysaccharide (CDPSSF) are significantly higher than those of the degraded polysaccharide (DPSF); the antioxidant activity of DPSF is higher than that of the nondegraded polysaccharide (PSF).

4.2. Carboxymethylated Polysaccharides Have Stronger Ability to Regulate CaOx Crystal Growth. Carboxymethylated polysaccharides can significantly inhibit COM crystal growth, induce COD crystal formation, and inhibit crystal aggregation (Figure 15).

First, after carboxymethylation, the content of $-\mathrm{COOH}$ in polysaccharides increases, which can complex a large number of $\mathrm{Ca}^{2+}$ ions in the system to inhibit the combination of $\mathrm{Ca}^{2+}$ and $\mathrm{Ox}^{2-}$ to form $\mathrm{CaOx}$ precipitates. The higher the degree of carboxymethylation is, the stronger the inhibitory ability will be.

Second, $\mathrm{Ca}^{2+}$ ions on the polysaccharide surface are highly enriched, forming a high energy interface because the carboxymethylated polysaccharide has enhanced ability to complex $\mathrm{Ca}^{2+}$ ions [54]. After $\mathrm{Ca}^{2+}$ ions are adsorbed, their degree of freedom decreases and the energy state of calcium increases, which are conducive to promoting the formation of COD [26]. 


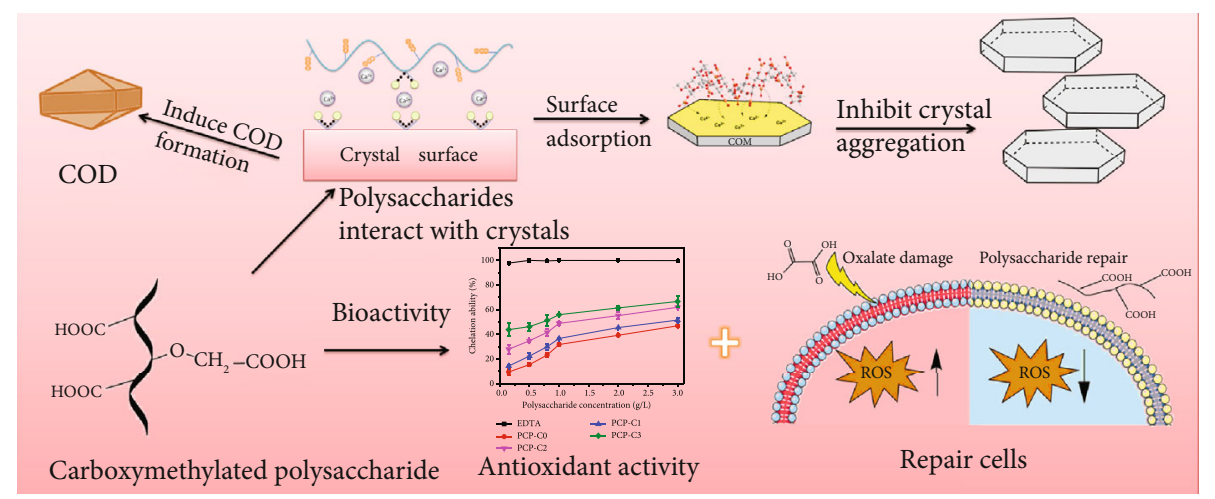

FIGURE 15: Model diagram of biological activity of carboxymethylated polysaccharides (PCP-Cs) and their regulatory effect on CaOx crystals.

TABLE 5: TGA curve analysis of CaOx crystals formed in the presence of $0.4 \mathrm{~g} / \mathrm{L}$ PCP-Cs and the blank group, respectively.

\begin{tabular}{|c|c|c|c|c|c|c|c|c|c|}
\hline \multirow[b]{2}{*}{$\begin{array}{l}\text { PCP- } \\
\text { Cs }\end{array}$} & \multicolumn{2}{|c|}{$\mathrm{A}$} & \multicolumn{2}{|c|}{$\mathrm{B}$} & \multicolumn{2}{|c|}{ C } & \multicolumn{2}{|c|}{$\mathrm{D}$} & \multirow[b]{2}{*}{$\begin{array}{r}\text { Residual } \\
\text { weight (\% }\end{array}$} \\
\hline & $\begin{array}{l}\text { Decomp. } T \\
\quad\left({ }^{\circ} \mathrm{C}\right) *{ }^{1}\end{array}$ & $\begin{array}{c}\text { Weight loss } \\
(\%)\end{array}$ & $\begin{array}{l}\text { Decomp. } T \\
\left({ }^{\circ} \mathrm{C}\right)\end{array}$ & $\begin{array}{c}\text { Weight loss } \\
(\%) *^{2}\end{array}$ & $\begin{array}{l}\text { Decomp. } T \\
\left({ }^{\circ} \mathrm{C}\right)\end{array}$ & $\begin{array}{c}\text { Weight loss } \\
(\%)\end{array}$ & $\begin{array}{l}\text { Decomp. T } \\
\left({ }^{\circ} \mathrm{C}\right)\end{array}$ & $\begin{array}{c}\text { Weight loss } \\
(\%)\end{array}$ & \\
\hline Blank & 95.73 & 12.08 & - & - & 409.14 & 18.33 & 552.94 & 28.99 & 36.55 \\
\hline $\begin{array}{l}\text { PCP- } \\
\text { C0 }\end{array}$ & 110.33 & 13.49 & 205.10 & 20.52 & 427.84 & 12.61 & 602.29 & 17.36 & 28.72 \\
\hline $\begin{array}{l}\text { PCP- } \\
\mathrm{C} 1\end{array}$ & 106.94 & 14.89 & 212.00 & 15.60 & 427.14 & 13.17 & 598.17 & 18.85 & 29.60 \\
\hline $\begin{array}{l}\text { PCP- } \\
\text { C2 }\end{array}$ & 107.68 & 16.62 & 212.67 & 10.65 & 426.54 & 13.93 & 605.64 & 21.23 & 30.95 \\
\hline $\begin{array}{l}\text { PCP- } \\
\text { C3 }\end{array}$ & 102.97 & 16.87 & 212.05 & 9.78 & 424.50 & 14.24 & 589.75 & 21.57 & 31.16 \\
\hline
\end{tabular}

${ }^{* 1}$ Decomp. T: decomposition temperature. ${ }^{* 2}$ The weight loss in stage B is the content of polysaccharides.

Third, the results of thermogravimetric analysis (Figure 11) showed that during the process of PCP-Cs regulating the growth of $\mathrm{CaOx}$, PCP-Cs were adsorbed or incorporated into the $\mathrm{CaOx}$ crystals (Table 5). The adsorption of PCP-Cs resulted in the accumulation of high-density negative charges on the surface of the $\mathrm{CaOx}$ crystals, causing the absolute value of the Zeta potential to increase (Figure 9), thereby inhibiting the aggregation of $\mathrm{CaOx}$ crystals. Zhang et al. [6] showed that Sargassum polysaccharide (SGP) can significantly inhibit the aggregation of COM crystals; the inhibition rate of SGP at a concentration of $0.5 \mathrm{~g} / \mathrm{L}$ on the aggregation of COM crystals is as high as $76.8 \%$.

Fourth, the $\mathrm{Ca}^{2+}$ ions at the tip and edge of the crystal are easy to coordinate with - $\mathrm{COOH}$ of polysaccharides in solution due to the dissociation-precipitation equilibrium between a large number of - $\mathrm{COOH}$ groups in carboxymethylated polysaccharide and the formed $\mathrm{CaOx}$ crystals. The continuous dissociation-precipitation finally makes the $\mathrm{CaOx}$ crystal blunt (Figure 8). Given that the damage degree of the sharp-edged COM crystal to renal epithelial cells is higher than that of the blunt COD crystal and the affinity between the COM with the positively charged surface and the damaged renal epithelial cells with the negatively charged surface is higher than that of the COD crystal $[53,54]$, COD is easier to be excreted out of the body with urine. PCP-Cs induce the formation of more or even all COD crystals, thereby reducing the risk of $\mathrm{CaOx}$ kidney stone formation.
As shown in Figure 8, the crystal size of the control group is significantly smaller due to the maximum supersaturation of $\mathrm{CaOx}$ in the control system without the polysaccharide and the maximum nucleation rate of the crystal. Under the condition of fixing the total amount of $\mathrm{CaOx}$, rapid nucleation reduced the average size of each crystal. This finding also explains why PCP-C3 has the strongest complexing ability with $\mathrm{CaOx}$, but the crystal size induced by PCP-C 3 does not decrease; i.e., the number of formed crystals is small, but the size is still large.

4.3. Carboxymethylated Polysaccharide Has Stronger Ability to Protect Renal Epithelial Cells from Oxalate Toxicity. High-level ROS can react with intracellular macromolecules rapidly, impairing the function of normal cells and even leading to cell death [51]. The increase of SOD activity in the organism implies an elevated ability to resist free radicalinduced damage in the organism. The change of MDA content reveals the level of lipid peroxidation and indirectly reflects the degree of cell injury. The concentration of 8OHdG is considered a marker of oxidative DNA damage. After protecting HK-2 cells with different degrees of carboxymethylated PCP-Cs, oxidative damage from oxalate can be alleviated, thereby increasing cell viability (Figure 12(b)) and superoxide dismutase activity (Figure 14(a)) and decreasing ROS level (Figure 13), MDA content (Figure 14(b)), and 8OHdG expression (Figure 14(c)). Thus, PCP-Cs can protect 
HK-2 cells from oxidative damage by oxalate and improve cellular antioxidant ability. PCP-C with a higher carboxymethylation degree has a stronger protection ability.

Zhang et al. [55] used thrombin to induce inflammation of rat endothelial progenitor cells (EPC) and found that Astragalus polysaccharide (APS) has a protective effect on injured endothelial progenitor cells. APS can block the nuclear factor kappa $\mathrm{B}(\mathrm{NF}-\kappa \mathrm{B})$ signaling in $\mathrm{EPC}$, upregulate the expression of the vascular endothelial growth factor (VEGF) and its receptor, and inhibit the expression of intercellular adhesion molecule-1 (ICAM-1) induced by thrombin, thereby protecting cells from damage. Li et al. [56] found that Chinese chive polysaccharide (CCP) can inhibit the oxidative damage to the kidney of mice with chronic renal failure (CRF). Sulfated polysaccharides from Codium fragile polysaccharide (CFCEPS) have protective effects on $\mathrm{H}_{2} \mathrm{O}_{2}$-induced oxidative stress-damaged cells [57]. After being protected by CFCEPS, the cell vitality is enhanced, the intracellular ROS level is reduced, and the cell apoptosis is inhibited.

Our results indicated that carboxymethylated PCP-Cs have the ability to inhibit calcium oxalate formation and resist the oxidative damage of oxalate in vitro. However, more in-depth molecular mechanisms and verification in vivo need to be further studied in the future.

\section{Conclusions}

Carboxymethylation of PCP-C0 with - $\mathrm{COOH}$ content of $2.54 \%$ was carried out, and three carboxymethylated polysaccharides with - $\mathrm{COOH}$ contents of $6.13 \%, 10.24 \%$, and $16.22 \%$ were obtained. Compared with PCP-C0, the carboxymethylated polysaccharides (PCP-Cs) can significantly enhance its antioxidant capacity, protect renal epithelial cells from oxidative damage, inhibit COM growth, induce COD formation, inhibit crystal aggregation, and increase the concentration of soluble $\mathrm{Ca}^{2+}$ ions in the system, all of which are beneficial to inhibit the formation of $\mathrm{CaOx}$ kidney stones. With increasing carboxymethylation degrees in PCP-Cs, its biological activity gradually increases. This study suggests that carboxymethylation of polysaccharides is an effective method to enhance biological activity and anticalculus ability. The higher the degree of carboxymethylation is, the stronger the activity of polysaccharides will be.

\section{Data Availability}

All the data supporting the results were shown in the paper and can be available from the corresponding authors.

\section{Conflicts of Interest}

The authors declare that they have no competing interests.

\section{Acknowledgments}

This work was supported by the National Natural Science Foundation of China (No. 21975105) and Research and Development Program Projects in Key Fields of Hunan Province (No. 2020SK2112).

\section{References}

[1] C.-Y. Li, L. Liu, Y. W. Zhao et al., "Repair of tea polysaccharide promotes the endocytosis of nanocalcium oxalate monohydrate by damaged HK-2 cells," Oxidative Medicine and Cellular Longevity, vol. 2020, Article ID 2198976, 12 pages, 2020.

[2] B. Akın, M. Öner, Y. Bayram, and K. D. Demadis, "Effects of carboxylate-modified, "green" inulin biopolymers on the crystal growth of calcium oxalate," Crystal Growth \& Design, vol. 8, no. 6, pp. 1997-2005, 2008.

[3] H. Liu, L.-H. Huang, X.-Y. Sun, and J.-M. Ouyang, "Highphosphorus environment promotes calcification of A7R5 cells induced by hydroxyapatite nanoparticles," Materials Science and Engineering: C, vol. 107, p. 110228, 2020.

[4] I. Wijesekara, R. Pangestuti, and S.-K. Kim, "Biological activities and potential health benefits of sulfated polysaccharides derived from marine algae," Carbohydrate Polymers, vol. 84, no. 1, pp. 14-21, 2011.

[5] Y. Yu, M. Shen, Q. Song, and J. Xie, "Biological activities and pharmaceutical applications of polysaccharide from natural resources: a review," Carbohydrate Polymers, vol. 183, pp. 91-101, 2018.

[6] C. Y. Zhang, W. H. Wu, J. Wang, and M. B. Lan, "Antioxidant properties of polysaccharide from the brown seaweed Sargassum graminifolium (Turn.), and its effects on calcium oxalate crystallization," Marine Drugs, vol. 10, no. 12, pp. 119-130, 2012.

[7] X. T. Ma, X. Y. Sun, K. Yu, B. S. Gui, Q. Gui, and J. M. Ouyang, "Effect of content of sulfate groups in seaweed polysaccharides on antioxidant activity and repair effect of subcellular organelles in injured HK-2 cells," Oxidative Medicine and Cellular Longevity, vol. 2017, Article ID 2542950, 13 pages, 2017.

[8] K. Teodosio Melo, R. Gomes Camara, M. Queiroz et al., "Evaluation of sulfated polysaccharides from the brown seaweed Dictyopteris justii as antioxidant agents and as inhibitors of the formation of calcium oxalate crystals," Molecules, vol. 18, no. 12, pp. 14543-14563, 2013.

[9] Z. Xu, S. Feng, S. Shen et al., "The antioxidant activities effect of neutral and acidic polysaccharides from Epimedium acuminatum Franch. on Caenorhabditis elegans," Carbohydrate Polymers, vol. 144, pp. 122-130, 2016.

[10] L. S. Huang, X. Y. Sun, Q. Gui, and J. M. Ouyang, "Effects of plant polysaccharides with different carboxyl group contents on calcium oxalate crystal growth," CrystEngComm, vol. 19, no. 32, pp. 4838-4847, 2017.

[11] Y. Wang, Q. Mo, Z. Li et al., "Effects of degree of carboxymethylation on physicochemical and biological properties of pachyman," International Journal of Biological Macromolecules, vol. 51, no. 5, pp. 1052-1056, 2012.

[12] F. Huang, X. Y. Sun, and J. M. Ouyang, "Preparation and characterization of selenized Astragalus polysaccharide and its inhibitory effect on kidney stones," Materials Science and Engineering: $C$, vol. 110, article 110732, 2020.

[13] X. Wang, Z. Zhang, and M. Zhao, "Carboxymethylation of polysaccharides from Tremella fuciformis for antioxidant and moisture-preserving activities," International Journal of Biological Macromolecules, vol. 72, pp. 526-530, 2015.

[14] Z. Duan, W. Duan, F. Li, Y. Li, P. Luo, and H. Liu, "Effect of carboxymethylation on properties of fucoidan from Laminaria japonica: Antioxidant activity and preservative effect on strawberry during cold storage," Postharvest Biology and Technology, vol. 151, pp. 127-133, 2019. 
[15] Y. Li, Y. Yuan, L. Lei et al., "Carboxymethylation of polysaccharide from Morchella angusticepes Peck enhances its cholesterol-lowering activity in rats," Carbohydrate Polymers, vol. 172, pp. 85-92, 2017.

[16] K. H. Lai, M. C. Lu, Y. C. du et al., "Cytotoxic lanostanoids from Poria cocos," Journal of Natural Products, vol. 79, no. 11, pp. 2805-2813, 2016.

[17] Y. Sun, "Biological activities and potential health benefits of polysaccharides from Poria cocos and their derivatives," International Journal of Biological Macromolecules, vol. 68, pp. 131-134, 2014.

[18] X. Jia, L. Ma, P. Li, M. Chen, and C. He, "Prospects of Poria cocos polysaccharides: Isolation process, structural features and bioactivities," Trends in Food Science \& Technology, vol. 54, pp. 52-62, 2016.

[19] Y. Wang, M. Zhang, D. Ruan et al., "Chemical components and molecular mass of six polysaccharides isolated from the sclerotium of Poria cocos," Carbohydrate Research, vol. 339, no. 2, pp. 327-334, 2004.

[20] N. Wang, Y. Zhang, X. Wang et al., "Antioxidant property of water-soluble polysaccharides from Poria cocos Wolf using different extraction methods," International Journal of Biological Macromolecules, vol. 83, pp. 103-110, 2016.

[21] K. Wu, J. Fan, X. Huang, X. Wu, and C. Guo, "Hepatoprotective effects exerted by Poria Cocos polysaccharides against acetaminophen-induced liver injury in mice," International Journal of Biological Macromolecules, vol. 114, pp. 137-142, 2018.

[22] H. Zhang, J.-Q. Wang, S.-P. Nie, Y.-X. Wang, S. W. Cui, and M.-Y. Xie, "Sulfated modification, characterization and property of a water-insoluble polysaccharide from Ganoderma atrum," International Journal of Biological Macromolecules, vol. 79, pp. 248-255, 2015.

[23] X. Sun, X. Jin, W. Pan, and J. Wang, "Syntheses of new rare earth complexes with carboxymethylated polysaccharides and evaluation of their in vitro antifungal activities," Carbohydrate Polymers, vol. 113, pp. 194-199, 2014.

[24] S. Li, Q. Xiong, X. Lai et al., "Molecular modification of polysaccharides and resulting bioactivities," Compr Rev Food Sci Food Saf, vol. 15, no. 2, pp. 237-250, 2016.

[25] Y. Y. Ren, P. P. Sun, Y. P. Ji, X. T. Wang, S. H. Dai, and Z. Y. Zhu, "Carboxymethylation and acetylation of the polysaccharide from Cordyceps militaris and their $\alpha$-glucosidase inhibitory activities," Natural Product Research, vol. 34, no. 3, pp. 369-377, 2020.

[26] J.-Y. Chen, X. Y. Sun, and J. M. Ouyang, "Modulation of calcium oxalate crystal growth and protection from oxidatively damaged renal epithelial cells of corn silk polysaccharides with different molecular weights," Oxidative Medicine and Cellular Longevity, vol. 2020, Article ID 6982948, 19 pages, 2020.

[27] W. Tang, L. Lin, J. Xie et al., "Effect of ultrasonic treatment on the physicochemical properties and antioxidant activities of polysaccharide from Cyclocarya paliurus," Carbohydr Polym, vol. 151, pp. 305-312, 2016.

[28] X. Pan, S. Wu, Y. Yan et al., "Rice bran polysaccharide-metal complexes showed safe antioxidant activity in vitro," International Journal of Biological Macromolecules, vol. 126, pp. 934-940, 2019.

[29] L. Chen and G. Huang, "Antioxidant activities of sulfated pumpkin polysaccharides," International Journal of Biological Macromolecules, vol. 126, pp. 743-746, 2019.
[30] G. Y. Xu, A. M. Liao, J. H. Huang, J. G. Zhang, K. Thakur, and Z. J. Wei, "Evaluation of structural, functional, and antioxidant potential of differentially extracted polysaccharides from potatoes peels," International Journal of Biological Macromolecules, vol. 129, pp. 778-785, 2019.

[31] J. Chung, I. Granja, M. G. Taylor, G. Mpourmpakis, J. R. Asplin, and J. D. Rimer, "Molecular modifiers reveal a mechanism of pathological crystal growth inhibition," Nature, vol. 536, no. 7617, pp. 446-450, 2016.

[32] X.-Y. Sun, H. Zhang, J. Liu, and J.-M. Ouyang, "Repair activity and crystal adhesion inhibition of polysaccharides with different molecular weights from red algae Porphyra yezoensis against oxalate-induced oxidative damage in renal epithelial cells," Food \& Function, vol. 10, no. 7, pp. 3851-3867, 2019.

[33] S. Duan, M. Zhao, B. Wu et al., "Preparation, characteristics, and antioxidant activities of carboxymethylated polysaccharides from blackcurrant fruits," International Journal of Biological Macromolecules, vol. 155, pp. 1114-1122, 2020.

[34] M. Shi, X. Wei, J. Xu et al., "Carboxymethylated degraded polysaccharides from Enteromorpha prolifera: Preparation and in vitro antioxidant activity," Food Chemistry, vol. 215, pp. 76-83, 2017.

[35] J. Tang, J. Nie, D. Li et al., "Characterization and antioxidant activities of degraded polysaccharides from Poria cocos sclerotium," Carbohydrate polymers., vol. 105, pp. 121-126, 2014.

[36] Y. Chen, H. Zhang, Y. Wang, S. Nie, C. Li, and M. Xie, “Acetylation and carboxymethylation of the polysaccharide from Ganoderma atrum and their antioxidant and immunomodulating activities," Food Chemistry, vol. 156, pp. 279-288, 2014.

[37] X. Chen, L. Zhang, and P. C. K. Cheung, "Immunopotentiation and anti-tumor activity of carboxymethylated-sulfated $\beta$ - $(1 \rightarrow 3)$-D-glucan from Poria cocos," International Immunopharmacology, vol. 10, no. 4, pp. 398-405, 2010.

[38] X. Li, Y. He, P. Zeng et al., "Molecular basis for Poria cocos mushroom polysaccharide used as an antitumour drug in China," Journal of Cellular and Molecular Medicine, vol. 23, no. 1, pp. 4-20, 2019.

[39] Z. Wang, J. Xie, M. Shen, S. Nie, and M. Xie, "Sulfated modification of polysaccharides: synthesis, characterization and bioactivities," Trends in Food Science \& Technology, vol. 74, pp. 147-157, 2018.

[40] Y. Yuan and D. Macquarrie, "Microwave assisted extraction of sulfated polysaccharides (fucoidan) from Ascophyllum nodosum and its antioxidant activity," Carbohydr Polym, vol. 129, pp. 101-107, 2015.

[41] H. Liu, X. Y. Sun, F. X. Wang, and J. M. Ouyang, "Regulation on calcium oxalate crystallization and protection on HK-2 cells of tea polysaccharides with different molecular weights," Oxidative Medicine and Cellular Longevity, vol. 2020, Article ID 5057123, 14 pages, 2020.

[42] X.-Y. Sun, C.-Y. Zhang, P. Bhadja, and J.-M. Ouyang, "Preparation, properties, formation mechanisms, and cytotoxicity of calcium oxalate monohydrate with various morphologies," CrystEngComm, vol. 20, no. 1, pp. 75-87, 2018.

[43] A. Stanković, B. Njegić Džakula, J. Kontrec, D. Kovačević, B. Marković, and D. Kralj, "Preparation and characterization of calcium oxalate dihydrate seeds suitable for crystal growth kinetic analyses," Journal of Crystal Growth, vol. 500, pp. 9197, 2018.

[44] V. S. Joshi, B. B. Parekh, M. J. Joshi, and A. B. Vaidya, "Herbal extracts of Tribulus terrestris and Bergenia ligulata inhibit 
growth of calcium oxalate monohydrate crystals in vitro," Journal of Crystal Growth, vol. 275, no. 1-2, pp. e1403-e1408, 2005.

[45] W. Fang, H. Zhang, J. Yin et al., "Hydroxyapatite crystal formation in the presence of polysaccharide," Crystal Growth \& Design, vol. 16, no. 3, pp. 1247-1255, 2016.

[46] W. Liu, C. Hu, Y. Liu et al., "Preparation, characterization, and $\alpha$-glycosidase inhibition activity of a carboxymethylated polysaccharide from the residue of Sarcandra glabra (Thunb.) Nakai," International Journal of Biological Macromolecules, vol. 99, pp. 454-464, 2017.

[47] M. K. Lu, J. J. Cheng, C. Y. Lin, and C. C. Chang, "Purification, structural elucidation, and anti-inflammatory effect of a watersoluble 1,6-branched 1,3- $\alpha$-d-galactan from cultured mycelia of Poria cocos," Food Chemistry, vol. 118, no. 2, pp. 349-356, 2010.

[48] Y. Liu and G. Huang, "The antioxidant activities of carboxymethylated cushaw polysaccharide," International Journal of Biological Macromolecules, vol. 121, pp. 666-670, 2019.

[49] L. Yang, T. Zhao, H. Wei et al., "Carboxymethylation of polysaccharides from Auricularia auricula and their antioxidant activities in vitro," International Journal of Biological Macromolecules, vol. 49, no. 5, pp. 1124-1130, 2011.

[50] J. Xu, W. Liu, W. Yao, X. Pang, D. Yin, and X. Gao, “Carboxymethylation of a polysaccharide extracted from Ganoderma lucidum enhances its antioxidant activities in vitro," Carbohydrate Polymers, vol. 78, no. 2, pp. 227-234, 2009.

[51] J. Wang, S. Hu, S. Nie, Q. Yu, and M. Xie, "Reviews on mechanisms of in vitro antioxidant activity of polysaccharides," Oxidative Medicine and Cellular Longevity, vol. 2016, Article ID 5692852, 13 pages, 2016.

[52] F. Y. Kagimura, M. A. A. da Cunha, T. V. Theis et al., "Carboxymethylation of $(1 \rightarrow 6)$ - $\beta$-glucan (lasiodiplodan): Preparation, characterization and antioxidant evaluation," Carbohydrate Polymers, vol. 127, pp. 390-399, 2015.

[53] Y. T. Li, B. J. Chen, W. D. Wu et al., "Antioxidant and antimicrobial evaluation of carboxymethylated and hydroxamated degraded polysaccharides from Sargassum fusiforme," International Journal of Biological Macromolecules, vol. 118, Part B, pp. 1550-1557, 2018.

[54] B. Grohe, K. A. Rogers, H. A. Goldberg, and G. K. Hunter, "Crystallization kinetics of calcium oxalate hydrates studied by scanning confocal interference microscopy," Journal of Crystal Growth, vol. 295, no. 2, pp. 148-157, 2006.

[55] X. Zhang, K. Yao, L. Ren, T. Chen, and D. Yao, "Protective effect of Astragalus polysaccharide on endothelial progenitor cells injured by thrombin," International Journal of Biological Macromolecules, vol. 82, pp. 711-718, 2016.

[56] Q. M. Li, H. R. Chena, X. Q. Zha, C. Q. Lu, L. H. Pan, and J. P. Luo, "Renoprotective effect of Chinese chive polysaccharides in adenine-induced chronic renal failure," International Journal of Biological Macromolecules, vol. 106, pp. 988-993, 2018.

[57] L. Wang, J. Y. Oh, J. G. Je et al., "Protective effects of sulfated polysaccharides isolated from the enzymatic digest of Codium fragile against hydrogen peroxide-induced oxidative stress in in vitro and in vivo models," Algal Research, vol. 48, article 101891, 2020. 